\title{
Food web interactions in the plankton of Long Island bays, with preliminary observations on brown tide effects
}

\author{
Darcy J. Lonsdale*, Elizabeth M. Cosper, Woong-Seo Kim**, Michael Doall, \\ Asha Divadeenam, Sigrun H. Jonasdottir***
}

Marine Sciences Research Center, State University of New York at Stony Brook, Stony Brook, New York 11794-5000, USA

\begin{abstract}
We examined the relative importance of phytoplankton and ciliates as prey for metazoan zooplankton, and the role of predation in regulating ciliate populations in 2 Long Island (USA) bays. Depth-integrated primary production $\left(\mathrm{mg} \mathrm{C} \mathrm{m}^{-2} \mathrm{~h}^{-1}\right)$ was dominated by nannoplankton $<5 \mu \mathrm{m}$ in diameter throughout the year, ranging from $>95 \%$ of total production in mid-summer to an average of about $60 \%$ in winter and early spring. Predator exclusion and addition experiments conducted in microcosms showed that the mortality coefficient of ciliates $\left(\mathrm{d}^{-1}\right)$ from zooplankton predation was higher when larger phytoplankton $(>10 \mu \mathrm{m})$ contributed less to total primary productivity. For adult copepods, an increase in the percentage ciliate contribution compared to phytoplankton contribution to total carbon intake also coincided with the higher percentages of small microalgal production. Egg production rates of Acartia spp. were posituvely correlated to the net growth coefficient of cilictes. In contrast, micrometazoa routinely obtained $>70 \%$ of their total carbon ration from phytoplankton, and at times during spring and summer, removed 23 to $52 \%$ of the total depth-integrated primary production. In addition to protozoa, we suggest that micrometazoa, particularly copepod nauplii, may serve as a trophic link between phytoplankton and mesozooplankton in Long Island bays
\end{abstract}

KEY WORDS: Zooplankton grazing and production Primary production Ciliates

\section{INTRODUCTION}

Temporal and spatial changes in phytoplankton abundance and composition reflect the dynamic nature of both physical and biological factors which contribute to the growth and loss of cells (reviewed in Frost 1980). In Long Island bays (New York, USA), diatoms are an important component of the late winter bloom, and are succeeded by smaller chrysophytes and chlorophytes in the summer months (Lively et al. 1983). Investigations of primary productivity in these bays (Great South Bay reviewed in Carpenter et al.

\footnotetext{
-E-mail: dlonsdale@ccmail.sunysb.edu

Present addresses:

- Korean Ocean Research and Development Institute, PO Box 29, Seoul 425-600, Korea

..Danish Institute for Fisheries and Marine Research, Charlottenlund Castle, DK-2920 Charlottenlund, Denmark
}

1991; Peconic Bays in Bruno et al. 1983, Cosper et al. 1989) showed that nannoplankton was the major contributor to planktonic primary production in summer. Such shifts in the composition and size structure of the phytoplankton community can have important effects on the fecundity and survivorship of zooplankton. For example, Kleppel (1992, Kleppel et al. 1991) has questioned the role of diatoms as 'optimal food for adult copepods in several locations (e.g. Acartia tonsa of the California coast), a hypothesis that has been supported recently in Long Island Sound studies (Jonasdottir 1994, Jonasdottir et al. 1995). Diatoms may also be an inferior food source compared to animal prey for some meroplankton (e.g. decapod larvae; Harms 1992). Exudates from diatoms in a stationary growth phase may actually inhibit copepod grazing (Malej \& Harris 1993). Ciliates, dinoflagellates and other protists may provide a better nutritional source to fuel copepod egg production compared to diatoms because of chemical differ- 
ences in specific fatty acids and protein content (Stoecker \& Capuzzo 1990 and references therein, Jonasdottir 1994)

The purpose of our study was to evaluate the relative importance of phytoplankton and ciliates in feeding and production of metazoan zooplankton in 2 Long Island bays. In recent years, the importance of protists, particularily phagotrophic ciliates and flagellates, in maintaining the coupling of phytoplankton productivity to zooplankton dynamics has become evident (Conover 1982, Landry \& Lehner-Fournier 1988, Sherr et al. 1988). Because smaller algae, particularly those $<5 \mu \mathrm{m}$, are more likely to be efficiently utilized by protozoa compared to adult copepods (Azam et al. 1983), we hypothesized that predation on ciliates would be critical for copepod diets (as found for Acartia tonsa; Robertson 1983, Gifford \& Dagg 1991) and production (Stoecker \& Egloff 1987, reviewed in Stoecker \& Capuzzo 1990), especially during summer when small nannoplankton dominate in Long Island bays. The specific objectives of this study were, firstly, to determine if there was seasonal variation in major food resources for mesozooplankton (>202 $\mu \mathrm{m}$ ) and micrometazoa (>64 to $202 \mu \mathrm{m}$ ) in Long Island Bays. Secondly, we investigated whether prey productivity influenced copepod productivity. Thirdly, we evaluated the role of zooplankton predators on the population dynamics of ciliates. During the course of this investigation a 'brown tide' occurred. This algal species, Aureococcus anophagefferens, is $\sim 2 \mu \mathrm{m}$ in diameter (Sieburth et al. 1988), and has toxic properties that cause growth and feeding reduction in some marine organisms (e.g. bay scallop larvae; Gallager et al. 1989). Dimethylsulfoniopropionate (DMSP), a precursor to dimethylsulfide (DMS) and acrylic acid, resides within the cell (Keller et al. 1989). The cell surface of A. anophagefferens contains a neurotransmittor-like, bioactive compound that reduces gill ciliary beat frequency in some bivalve species (e.g Mercenaria mercenaria; Gainey \& Shumway 1991).

\section{METHODS}

Field sampling. Our sampling sites during 1991 included 1 station (Blue Point on $2 / 12,3 / 21,4 / 16,5 / 2$, $7 / 25,7 / 31,11 / 25$; dates expressed as month/day) in the Great South Bay (GSB) and 2 stations in the Peconic Bays (PB) (Reeves Bay on 5/20,5/21, and West Neck Bay on 6/17, 6/20, 7/17, 7/22) (Fig. 1). Both primary productivity and zooplankton feeding experiments were conducted on each experimental date except on $5 / 2,5 / 20,6 / 20$ when only the former was measured. Sampling was conducted from piers or docks at a $0.5 \mathrm{~m}$ depth for temperature and salinity measurements, zooplankton abundance, and ambient seawater collection. Strong vertical mixing of these shallow water bodies over large areas alleviated the necessity for water column depth profiles (Bruno et al. 1983, Lively et al. 1983).

Zooplankton composition and abundance. Larger zooplankton were collected and size fractionated by successively passing buckets of water (20 l) through Nitex sieves; $202 \mu \mathrm{m}$ and $64 \mu \mathrm{m}$ for mesozooplankton and micrometazoa, respectively ( $\mathrm{n}=2$ for each size fraction). Animals caught on the sieves were rinsed with $0.22 \mu \mathrm{m}$ filtered seawater into jars, preserved in $5 \%$ buffered formalin and enumerated under a dissecting microscope. Additional samples of whole seawater (400 $\mathrm{ml}, \mathrm{n}=2$ ) were collected and preserved in Lugol's fixative $(\sim 10 \%)$ for enumeration of more delicate ciliates. Lugol's samples were allowed to settle for $\sim 8 \mathrm{~h}$ in the sampling jar, followed by removal of 300 to $350 \mathrm{ml}$ of the overlying water. The remaining contents

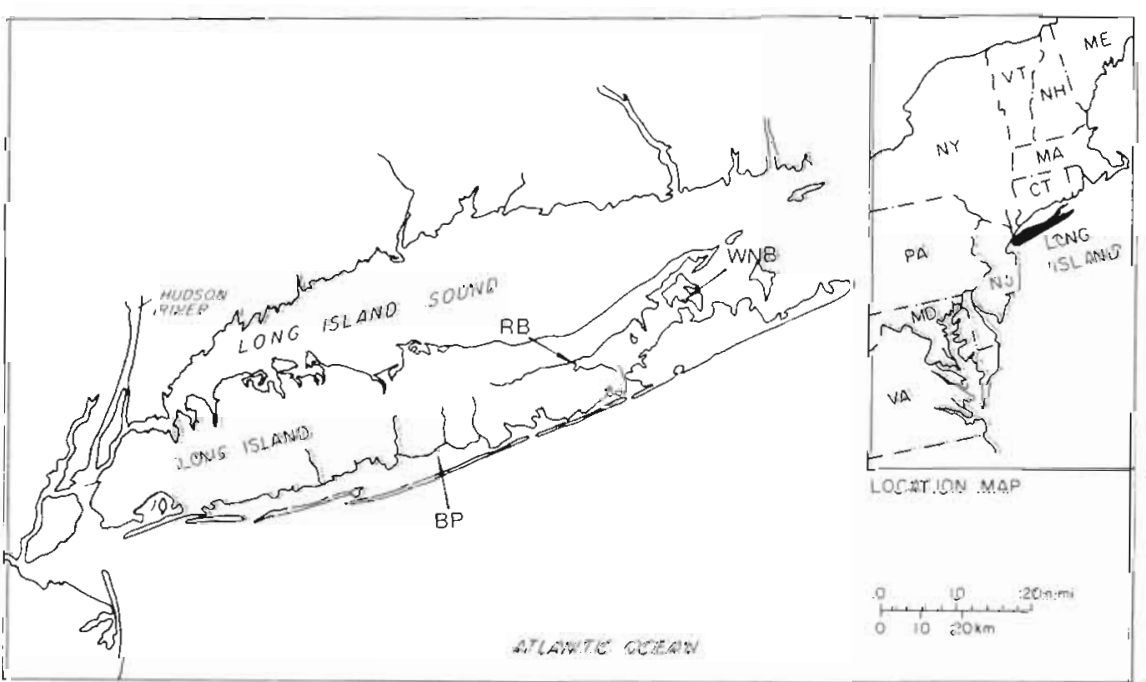

Fig. 1. Location of sampling sites in the Peconic Bays (RB: Reeves Bay; WNB: West Neck Bay) and Great South Bay (BP: Blue Point) 
were then placed in a graduated cylinder, and allowed to settle for an additional $24 \mathrm{~h}$. All but $5 \mathrm{ml}$ of the overlying water was removed and protozoa were counted by $1 \mathrm{ml}$ aliquots in a counting chamber until at least 100 ciliates were counted. A Zeiss compound microscope equipped with a micrometer was used for enumeration and measurement of ciliates $>20 \mu \mathrm{m}$.

Primary productivity and phytoplankton biomass. Phytoplankton biomass was estimated from $90 \%$ acetone-extracted chlorophyll a (chl a) by fluorometry using a Turner designs fluorometer (Strickland \& Parsons 1972, Cosper et al. 1989). Ambient seawater samples ( $30 \mathrm{ml}$ ) were size fractionated to obtain $<5,<10$ and $<20 \mu \mathrm{m}$ fractions using Nitex netting, as well as whole water samples ( $\mathrm{n}=3$ to 6 for each fraction). Total and size-fractionated primary productivity rates were obtained following simulated in situ, short-term incubations ( 2 to $4 \mathrm{~h}$ ) with ${ }^{14} \mathrm{C}-\mathrm{NaHCO}_{3}$ under a range of light intensities including 100, 33 and $2 \%$ ambient light using neutral screening and $0 \%$ in dark bottles (Cosper et al. 1989). The ${ }^{14} \mathrm{C}-\mathrm{NaHCO}_{3}$ was added from a stock solution to a final concentration of $\sim 0.2 \mu \mathrm{Ci} \mathrm{ml}{ }^{-1}$. Whole seawater incubations were terminated by size fractionation and filtered onto $0.22 \mu \mathrm{m}$ Millipore filters. Filters were placed in scintillation vials and dried in a desiccator overnight to volatilize any remaining inorganic ${ }^{14} \mathrm{C}$. The particulate ${ }^{14} \mathrm{C}$ on the filters was counted in a Packard Tricarb $300 \mathrm{C}$ scintillation counter after the addition of $5 \mathrm{ml}$ of opti-fluor scintillation liquid. Integral estimates of photic zone production were calculated based on field light extinction coefficients.

Cell counts of Aureococcus anophagefferens were conducted using the immunofluorescent detection method (Anderson et al. 1989), and at least 100 other larger species were identified from Lugol's samples using an inverted light microscope at $600 \times$ magnification.

Zooplankton grazing on the natural phytoplankton community. The algae Nannochloris sp. (chlorophyte; $<5 \mu \mathrm{m}$ in diameter), Thalassiosira pseudonana (diatom; 5 to $10 \mu \mathrm{m}$ ), Thalassiosira weissflogii (diatom; 10 to $20 \mu \mathrm{m}$ ) and Ditylum brightwelli (diatom; $>20 \mu \mathrm{m}$ ) were radiolabeled with ${ }^{14} \mathrm{C}-\mathrm{NaHCO}_{3}$ and used as tracers of in situ zooplankton grazing on natural phytoplankton (modified from Lampert \& Taylor 1985, Lampert et al. 1986). A 1 l, semi-continuous culture of each microalgal species was maintained in exponential growth throughout the duration of the project. Dilutions were performed asceptically in a sterile transfer hood. Stock cultures were grown in $\mathrm{f} / 2$ enriched Instant Ocean prepared at a salinity of $30 \mathrm{ppt}$ (Guillard \& Ryther 1962), and were maintained at $20^{\circ} \mathrm{C}$ on a $12: 12 \mathrm{~h}$ light: dark cycle at a light intensity of $\sim 100 \mu \mathrm{E} \mathrm{m} \mathrm{m}^{-2} \mathrm{~s}^{-1}$.

Exponentially growing algae were dispensed aseptically from stock cultures into sterile, polystyrene flasks for inoculations with radioactive sodium bicarbonate. These cultures were maintained under the same growth conditions as the stock cultures for $48 \mathrm{~h}$ prior to the experiment to ensure uniform radioactive labeling of cells.

Seawater for the grazing experiments was collected by bucket, placed into $20 \mathrm{l}$ cubitainers, and transported to and held in the laboratory in coolers to maintain ambient temperature. Sampling was conducted in the morning, most often between 07:00 and 10:00 h. Grazing experiments generally began within $3 \mathrm{~h}$ after seawater collection. All experiments were conducted at ambient temperature $\left( \pm 1.0^{\circ} \mathrm{C}\right)$. Cubitainers were rotated gently by hand prior to pouring into the grazing chambers (1.5 l glass or 21 polycarbonate bottles wrapped in black plastic). The grazing chambers were then placed in coolers for temperature control, and the zooplankton allowed to 'recover' for approximately 15 to $30 \mathrm{~min}$ prior to the grazing experiment. Usually there were $n=4$ for each microalgal tracer species and for each sampling date.

The total amount of radiolabeled algal suspension added to the grazing chambers represented 5 to $20 \%$ of the carbon concentration ( $\mu \mathrm{C} \mathrm{Cl}^{-1}$ ) of the representative phytoplankton size fraction determined just prior to experimentation by measuring chl a concentration of the sampled water and converting to carbon assuming a $\mathrm{C}$ :chl a ratio of 45 , which is a reasonable conversion based on studies in waters with similar phytoplankton composition (i.e. Long Island Sound; Tantichodok 1990). The cell concentration of each culture of radiolabeled microalgae was determined just prior to experimentation, and estimates of cell carbon content were obtained using the Strathmann equation (Strathmann 1967).

Following inoculation with the microalgal suspension, the chamber was rotated gently by hand, and the experiment allowed to run for only $7 \mathrm{~min}$ to minimize error from recycling of dissolved organic carbon or coprophagy. Also, previous time-course grazing experiments using this technique showed no significant change or a decline in the estimate of zooplankton grazing with increased incubation time (Lonsdale \& Cosper 1994). The chamber contents were sieved successively through $>202 \mu \mathrm{m}$ and $>64 \mu \mathrm{m}$ Nitex netting. Contents caught on the sieve were gently sprayed with $0.45 \mu \mathrm{m}$ filtered seawater to remove unconsumed, radiolabeled cells, and then rinsed onto $0.22 \mu \mathrm{m}$ Millipore filters. The contents were then prepared for scintillation counting as described above for primary productivity experiments. On each sampling date, 5 to $30 \mathrm{ml}$ samples of the radiolabeled algae were prepared for scintillation counting $(n=3)$ to convert radioactivity measurements to cell number. Thus, our grazing measurement technique accounted 
for cell-size dependent differences in radiolabeling (Tackx \& Daro 1993).

To account for radiolabel uptake by zooplankton not related to grazing (e.g. naupliar 'drinking'; Tester \& Turner 1991), controls were conducted using the same amount of radiolabeled suspension as in the grazing experiments, but first passed through a $0.22 \mu \mathrm{m}$ Millipore filter, and then added to grazing chambers as above. Filtrate controls $(n=2)$ were conducted for each microalgal tracer and experimental date. A second series of controls was conducted once to determine to what extent radiolabeled cells were retained successively on $202 \mu \mathrm{m}$ and $64 \mu \mathrm{m}$ sieves. Grazing chambers containing ambient filtered seawater $(0.45 \mu \mathrm{m})$ were inoculated with algal suspension at 5 representative concentrations (cells $\mathrm{ml}^{-1} ; \mathrm{n}=4$ to 12 for each concentration), followed by size-fractionated sieving, and scintillation counting (see Lonsdale \& Cosper 1994).

Zooplankton clearance rates were calculated from control-corrected data. Carbon ingestion rates $(\mu \mathrm{g} \mathrm{C}$ ind.$^{-1} \mathrm{~h}^{-1}$ ) of the 4 size fractions of phytoplankton were calculated from clearance rates ( $\mathrm{ml}$ ind. ${ }^{-1} \mathrm{~h}^{-1}$ ) and phytoplankton carbon concentration ( $\mu \mathrm{g} \mathrm{C}^{-1}$ ). Total carbon ingestion rate was determined from summation of the ingestion rates of the 4 size fractions. In several cases, no phytoplankton biomass was measured but minimal primary production was detected. Thus, carbon ingestion rates were obtained from zooplankton clearance and primary productivity rates ( $\left.\mu \mathrm{g} \mathrm{Cl}^{-1} \mathrm{~h}^{-1}\right)$.

Zooplankton predation and population growth of ciliates. Estimates of mesozooplankton and micrometazoan predation on ciliates were obtained using a predator removal/addition method. Incubation bottles (2 I polycarbonate bottles) were filled with whole seawater (WSW) or size-fractionated seawater to remove the $>202$ or al. $>64 \mu \mathrm{m}$ zooplankton predators $(\mathrm{n}=2$ for each treatment). The latter treatment was used to estimate the net growth coefficient of ciliates $\leq 64 \mu \mathrm{m}\left(\mathrm{d}^{-1}\right.$; sensu Frost 1972, Stoecker et al. 1983), and the other treatments to assess the predatory impact on ciliates of all larger $(>64 \mu \mathrm{m})$ zooplankton (WSW control measured the realized rate of ciliate population increase), or only the micrometazoa (>64 to $202 \mu \mathrm{m}_{i}>202 \mu \mathrm{m}$ removal treatment). We use the term 'net growth' to describe ciliate production available to larger zooplankton, recognizing that cannibalism or parasitism may occur (e.g. Stoecker et al. 1983). Bottles were incubated for about $24 \mathrm{~h}$ outdoors in water tanks at $40 \%$ natural sunlight by using neutral density screening. Water temperature was maintained close to ambient with ice and/or running tap water. Initial microzooplankton samples ( $400 \mathrm{ml}, \mathrm{n}=2$; Lugol's preserved) were taken from treatment and control waters, and again at the termination of the experiment for each incubation bottle. Ciliates were counted using the same methods described above, including being counted in $1 \mathrm{ml}$ aliquots of settled sample in a counting chamber until at least 100 individuals were counted.

The net growth coefficient of ciliates $\left(\mathrm{d}^{-1}\right)$, zooplankton predation coefficient (or mortality coefficient of ciliates; $\mathrm{d}^{-1}$ ), and zooplankton predation rate (ciliates ind. ${ }^{-1} \mathrm{~d}^{-1}$ ) were calculated using the equations of Frost (1972). Some error in the estimation of zooplankton predation may have occurred, however, if the net growth coefficient of ciliates in the sieved treatment did not match that in WSW. Carbon ingestion rates from ciliate prey were estimated by volume:carbon relationships for tíntinnids (Verity \& Langdon 1984) and aloricate ciliates (Putt \& Stoecker 1989). Aloricate ciliates ( $n=5$ on each date) were assumed to be ball shaped, and the diameter (d) of the cell was measured and its volume assumed to be equal to $4 / 3 \pi(d / 2)^{3}$. Tintinnids $(n=5)$ were assumed to approximate a cylinder and thus both the length ( $I$ ) and diameter of the lorica were measured and the volume of a cell was estimated by $\pi(d / 2)^{2} l$. Although zooplankton clearance rates $(\mathrm{ml}$ ind. ${ }^{1} \mathrm{~d}^{-1}$ ) were calculated for the total ciliate population, carbon ingestion rates were calculated separately from grazing rates on each ciliate type, and then totaled.

Adults and nauplii of the abundant copepod species were sorted from cod-end, $64 \mu \mathrm{m}$ net hauls to provide additional information on the predatory impact of mesozooplankton and micrometazoa, respectively, on population growth of ciliates. Ten adults or 50 nauplii were added to 21 polycarbonate bottles containing unfiltered seawater ( $\mathrm{n}=2$ for each copepod treatment). Before being added to bottles, individual copepods were transferred 3 times to $0.22 \mu \mathrm{m}$ filtered seawater with a pipet to minimize the introduction of other plankton. Sampling protocols and incubation conditions were as described for predator removal studies. Zooplankton predation coefficients were calculated using the realized ciliate growth coefficient calculated from WSW incubations, rather than the net growth coefficient as in the removal experiments.

Copepod egg production and hatching success. To determine if egg production rates of the most common copepods were food-limited (sensu Durbin et al. 1983), or influenced by prey availability, 5 to 6 females of the most common species [i.e. Acartia hudsonica (Piley) and Acartia tonsa Dana] were put into each of 8 to 12 plexiglass cylinders with a $202 \mu \mathrm{m}$ Nitex mesh on the lower end, and hung inside $1 \mathrm{l}$ beakers. The $202 \mu \mathrm{m}$ mesh in the inner containers allowed eggs to pass through, and kept females separate to minimize egg canmibalism. Half the beakers were filled with $800 \mathrm{ml}$ of $64 \mu \mathrm{m}$ screened ambient water, and the remaining with $800 \mathrm{ml}$ of enriched, screened ambient water. The screening was needed to remove any copepod eggs 
and nauplii present in the water. Enrichment consisted of adding the flagellate Rhodomonas lens 7 to $8 \mu \mathrm{m}$ diameter) to achieve a minimum of $2.0 \times 10^{4}$ cells $\mathrm{ml}^{-1}$. This microalgal species has been found to be a good food source for Acartia spp., and the experimental density is above the critical concentration for growth (Jonasdottir 1994). Beakers were incubated at ambient temperatures (usually $\pm 1^{\circ} \mathrm{C}$ ) in dim light on a $14: 10 \mathrm{~h}$ light:dark cycle. Egg production rates under ambient food conditions were determined after $24 \mathrm{~h}$. Copepods in the enriched beakers were allowed to acclimate to the new food for $24 \mathrm{~h}$. Following acclimation, the water was screened again through a $64 \mu \mathrm{m}$ mesh to remove eggs and nauplii, and animals were placed back in the same enriched water for another $24 \mathrm{~h}$ incubation. All eggs and nauplii were counted, and eggs were placed in culture plate wells $(20 \mathrm{ml})$ to determine egg hatching success (\%). Eggs were observed once a day for 2 to $4 \mathrm{~d}$ to measure hatching success. Hatching success for eggs produced under ambient food conditions was always determined, but not until $5 / 21$ for eggs produced under enriched conditions. Percentage hatching of eggs under ambient conditions was not available on $7 / 17$ because of their inadvertent loss following counting.

Copepod development and survival with brown tide. To evaluate further how Aureococcus anophagefferens impacts the growth of copepods, N I to N II nauplii of the meroplanktonic harpacticoid Coullana canadensis and mostly N VI of Acartia hudsonica were taken from laboratory batch cultures maintained at $20^{\circ} \mathrm{C}$ and $16^{\circ} \mathrm{C}$, respectively, a salinity of $25 \%$ and under a 14:10 h light: dark cycle (see Lonsdale \& Levinton 1985 for detail). A. hudsonica is common in Long Island bays from winter through late spring (e.g. Great South Bay; Duguay et al. 1989, this study), while $C$. canadensis nauplii have been found in summer (e.g. Quantuck Creek on the south shore; Lonsdale et al. 1993).

Five food treatments were utilized; ambient (nonbloom) seawater (26\%, sieved through $44 \mu \mathrm{m}$ mesh netting) or ambient-enriched with either a bloom concentration of Aureococcus anophagefferens (5 × $10^{5}$ cells $\left.\mathrm{ml}^{-1}\right)$ or Thalassiosira pseudonana $(3 \mathrm{H})(1.22 \times$ $10^{5}$ cells $\mathrm{ml}^{-1}$ ). Both additions were equivalent to $1100 \mu \mathrm{g} \mathrm{Cl}^{-1}$ according to the equations of Strathmann (1967). Alternatively, copepods were reared in autoclaved, filtered $(20 \mu \mathrm{m})$ seawater $(25 \%)$, with or without a suspension of $A$. anophagefferens cells $\left(5 \times 10^{5}\right.$ cells $\mathrm{ml}^{-1}$ ). Water temperature and the light cycle were the same as for batch culturing of copepods. The various copepod growth media were prepared fresh daily.

Nauplii and copepodites ( $n=18$ for each food treatment and life stage) were placed individually in $1 \mathrm{ml}$ wells of a multi-depression dish contained within an airtight white plastic box. Distilled water in the bottom of the box served to reduce evaporation from the wells. Observations on copepod survival and molting were made twice daily. All of the copepod growth suspension was replaced during the day, and $50 \%$ was replaced at night. Observations were made for $4.5 \mathrm{~d}$. Percentage survival was calculated from the number of individuals surviving from NI to CI for Coullana canadensis and N VI to C III for Acartia hudsonica, and included those surviving to the end of the experimental period if the final developmental stage had not been reached. Development times (h) used in the data analyses were from only those copepods which reached either CI (C. canadensis) or C III (A. hudsonica)

Statistical analyses. Prior to analysis of variance and multiple regression, Bartlett's test or the $F_{\max }$ test was used to verify that variances around the mean, including those of transformed data, were homogeneous (Sokal \& Rohlf 1981; pc statistical package). For multiple regression, a sample size of 1 was included in the data set (Sokal \& Rohlf 1981). Statistical analyses were conducted using either SAS (Analysis of Variance) or the pc statistical package accompanying Sokal \& Rohlf (1981; Linear Regression, Multiple Regression, TukeyKramer procedure and $\mathrm{R} \times \mathrm{C}$ Test of Independence).

\section{RESULTS}

\section{Primary productivity rates and biomass}

The highest rates of depth-integrated primary production (Fig. 2) were measured in the summer months, and this can be attributed to increasing water temperature (Fig. 3). A multiple regression of the dependence of total primary productivity $\left(\mathrm{mg} \mathrm{C} \mathrm{m} \mathrm{C}^{-2} \mathrm{~h}^{-2}, \log _{10}\right.$ transformed) on water temperature $\left({ }^{\circ} \mathrm{C}\right)$ and total chl a showed only water temperature to be significantly related (df $=1,10, F=20.436, p<0.001$ and $F=1.156$, $p>0.25$, respectively). The model explained $67.6 \%$ of the variance and was significant at the 0.005 level ( $\mathrm{df}=$ $2,10, F=10.426$ ). The major contributor to the total depth-integrated rate of primary production on all sampling dates was phytoplankton $<5 \mu \mathrm{m}$ in diameter. The range of contribution of these small phytoplankton to the total primary production was 45.8 to $95.7 \%$, being greatest in the summer months and lowest during winter and spring. The next-largest size fraction ( 5 to $10 \mu \mathrm{m}$ ) contributed nominally to phytoplankton community productivity (range $=0$ to $6.7 \%$ ). The contribution to primary production by the larger phytoplankton ( $>10 \mu \mathrm{m}$ ) ranged from 5 to $47.9 \%$, and in general was greatest between February and early May.

Chl a concentration had a similar trend as found for primary productivity (Fig. 4). The $5 \mu \mathrm{m}$ fraction was 


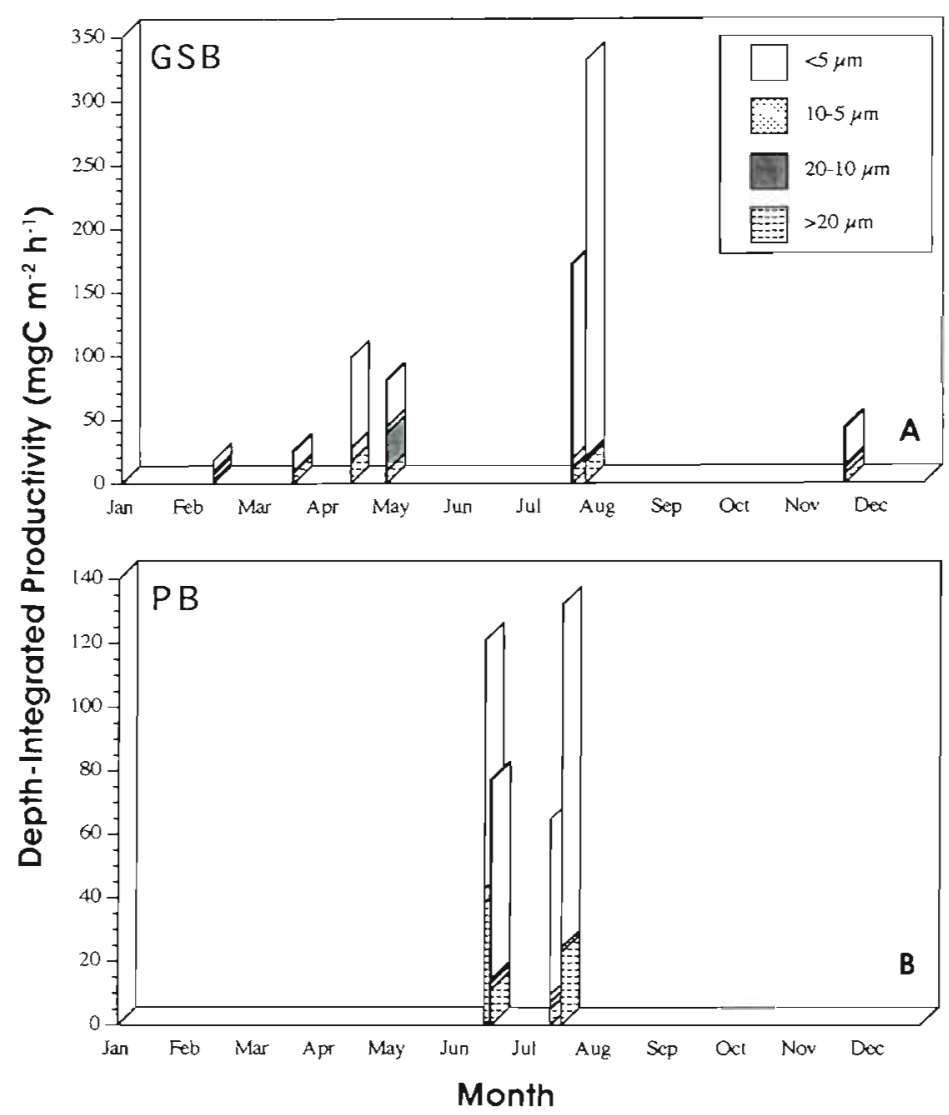

Fig. 2. Depth-integrated rate of primary productivity of 4 size fractions of phytoplankton in (A) Great South Bay, (B) Peconic Bays. Total depth-integrated rate of primary productivity is represented by the entire bar

ton, and the pennate diatom Cylindrotheca closterium was the most abundant component of the $>20 \mu \mathrm{m}$ size fraction. A few Gymnodinium spp. were also noted. During the early spring (3/21), the $>20 \mu \mathrm{m}$ size fraction was composed of the centric diatoms Coscinodiscus sp. ( $\sim 70$ to $100 \mu \mathrm{m})$, Rhizosolenia setigera, and Rhizosolenia sp., and the dinoflagellates Prorocentrum sp., Gymnodinium spp., and Protoperidinium bipes.

\section{Zooplankton abundances}

Late-stage copepodites and adult copepods, primarily Acartia spp. (A. hudsonica from February through May, and $A$. tonsa in June and July), comprised most of the mesozooplankton size fraction (>202 $\mu m_{i}$ Fig. 6). The micrometazoan size fraction ( $>64 \mu \mathrm{m}$ to $202 \mu \mathrm{m}$ ) was com-

always the major component, ranging from 50 to $99.3 \%$ of the total phytoplankton biomass. Chl a concentration also was related to water temperature (linear regression; $\log _{10} y=0.853+0.015 x_{i} \mathrm{df}=1,49$, $F=10.321,0.001<\mathrm{p}<0.005)$.

A bloom of Aureococcus anophagefferens occurred in West Neck Bay of the Peconic Bays system during June and July, and reached a peak concentration of $1.43 \times 10^{6}$ cells $\mathrm{ml}^{-1}$ on $6 / 17$ (Fig. 5). By $7 / 22$, the bloom had dissipated, and the concentration of this picoplankter was only $2.74 \times 10^{4}$ cells $\mathrm{ml}^{-1}$. Dinoflagellates were also abundant during the brown tide peak, including Dinophysis acuminata (30 to $40 \mu \mathrm{m}$, 'red tide'), Gymnodinium spp. (>20 $\mu \mathrm{m}$, 'red tide'), and Polykrikos kofoidi (60 to $80 \mu \mathrm{m}$, a heterotrophic dinoflagellate). During the decline of the brown tide (7/22), Gymnodinium spp. $(\geq 20 \mu \mathrm{m})$ and Protoperidinium sp. $(\geq 20 \mu \mathrm{m}$, a het erotroph) were noted. In GSB during the same summer period (7/25), a Nannochloris-like sp. (chlorophyte $\sim 2 \mu \mathrm{m}$ in diameter) was the major component of the $<5 \mu \mathrm{m}$ size fraction of planktonic phytoplank-

Fig. 3. (A) Water temperature and (B) salinity in Great South Bay (GSB) and the Peconic Bays (PB)
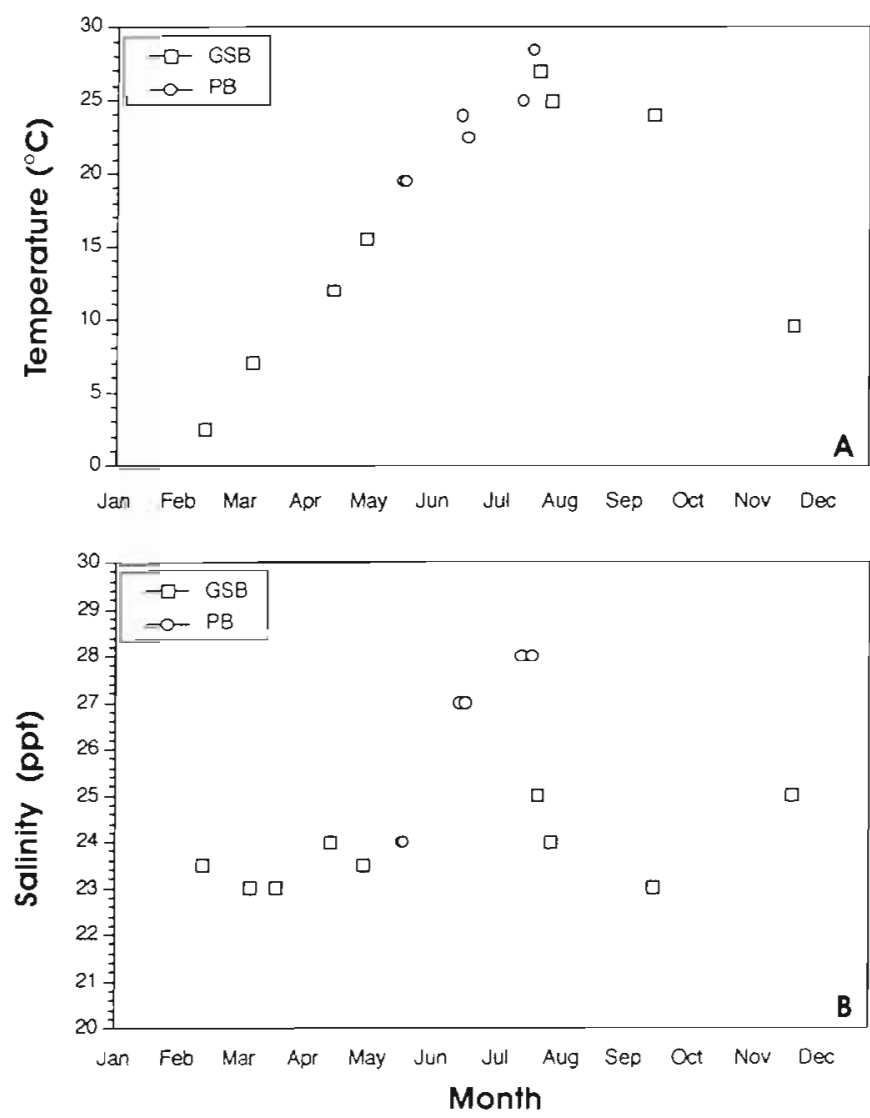


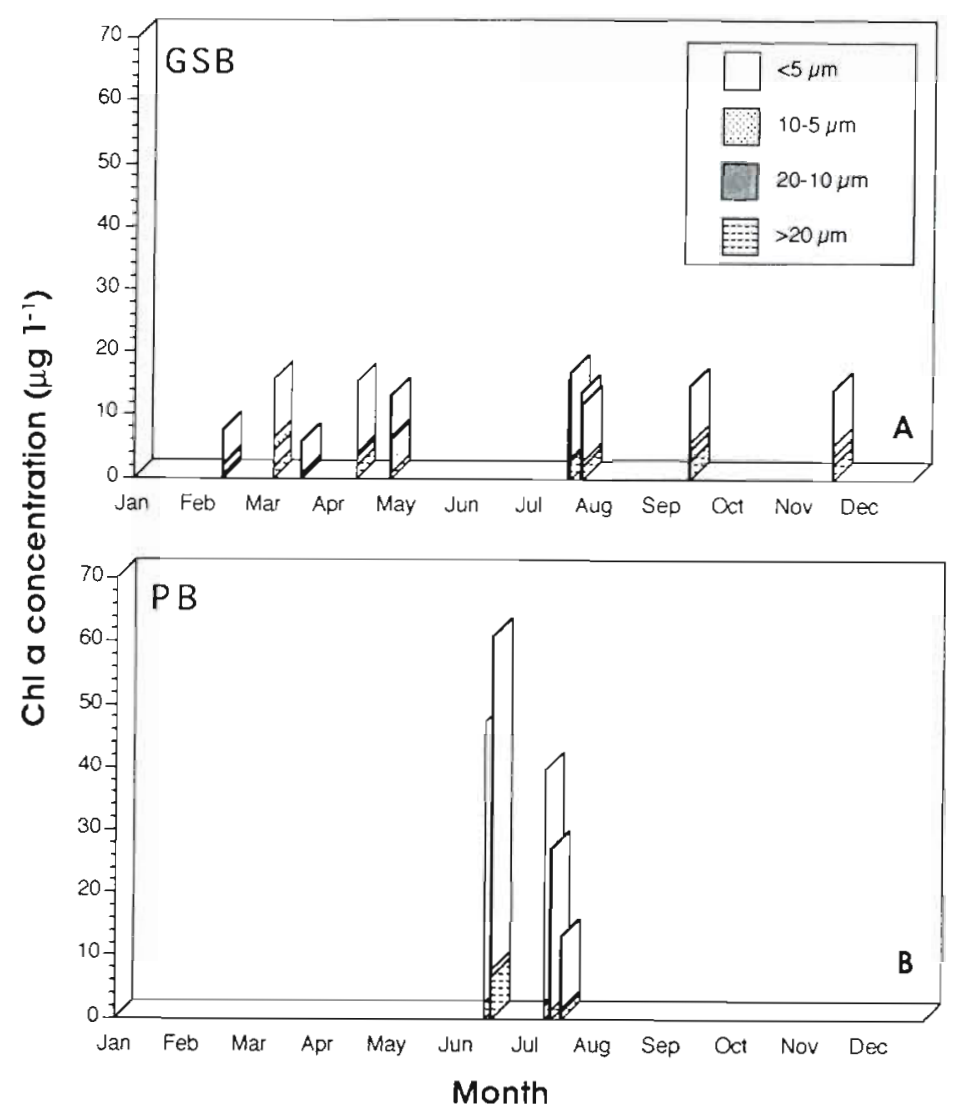

Fig. 4. Chlorophyll a concentration of 4 size fractions of phytoplankton in (A) Great South Bay, (B) Peconic Bays. Total $\mathrm{chl}$ a concentration is represented by the entire bar

represented by tintinnids and aloricate ciliates. The latter group were primarily oligotrichs in the family Strombididae. Scuticociliates were also frequently found. Following the decline of the brown tide in $\mathrm{PB}(7 / 22)$, however, the population was composed almost exclusively of small ( 30 to $40 \mu \mathrm{m})$, aloricate ciliates at a density $>20000 \mathrm{l}^{-1}$.

\section{Population dynamics of ciliates}

Multiple regression analysis revealed that the net growth coefficient of ciliate populations $\left(\mathrm{d}^{-1} ;\right.$ Fig. 8) determined from grazer removal experiments was significantly correlated with water temperature (Table 2). Net growth coefficients were positive throughout the sampling period except in February in GSB when water temperature was the lowest $\left(2.5^{\circ} \mathrm{C}\right)$, and during the peak of brown tide in $\mathrm{PB}(6 / 17)$. The highest rate of population increase was $1.24 \mathrm{~d}^{-1}$

prised mostly of copepod nauplii and meroplanktonic larvae (Fig. 6, Table 1) except on 7/25 and 7/31 when large tintinnids were also abundant. The mean density of total metazoan zooplankton was substantially lower in PB compared to GSB not only during the brown tide (27.1 vs $671.2 \mathrm{1}^{-1}$, respectively, June and July comparison), but also in the spring (147.7 vs $729.5 \mathrm{l}^{-1}$, May and April comparison)

Ciliates were most abundant in the $\sim 20$ to $\leq 64 \mu \mathrm{m}$ size fraction (Fig. 7), and throughout the year were

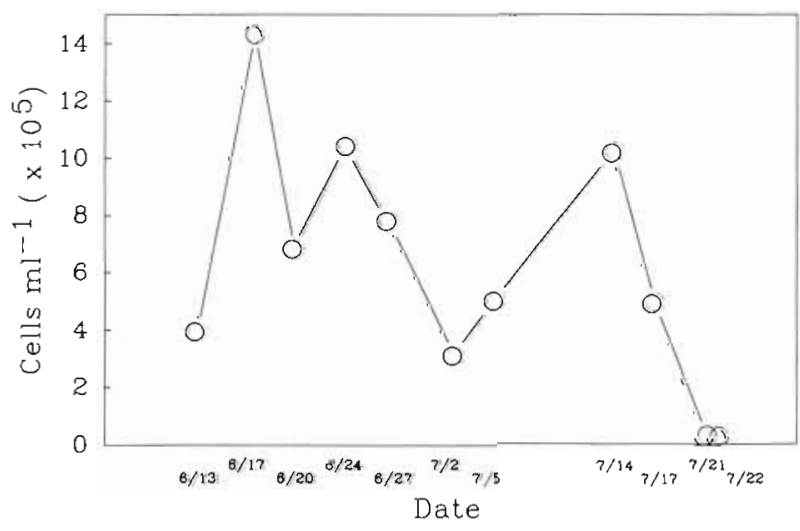

Fig. 5. Concentration of Aureococcus anophagefferens in West Neck Bay, PB during 1991 Dates given as Month/Day in PB during May. This analysis also showed a significant negative effect of cell concentration of Aureococcus anophagefferens on ciliate population growth. Salinity $(\%)$ and total and $<10 \mu \mathrm{m}$ depth-integrated primary productivity ( $\mathrm{mg} \mathrm{C} \mathrm{m}^{-2} \mathrm{~h}^{-1}$ ) were not significant variables that explained variation in the net growth coefficient of ciliates (Table 2). These results suggest that growth of ciliates is not limited

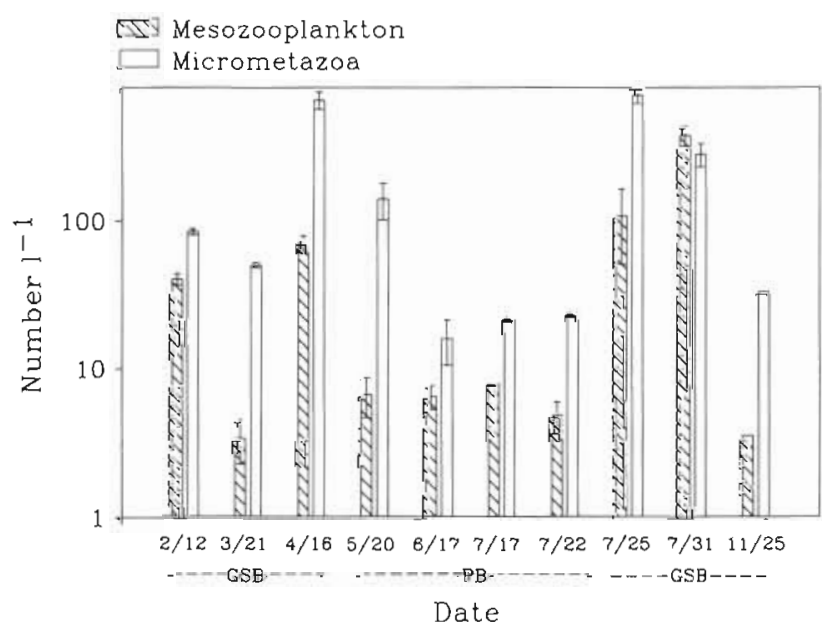

Fig. 6. Abundance (mean \pm range, $n=2$ ) of mesozooplankton and micrometazoa 
Table 1. Abundance (number $1^{-1}$ ) of the most common zooplankton taxa $>64$ to $202 \mu \mathrm{m}$ in Great South Bay (GSB) and the Peconic Bays (FB) during 1991

\begin{tabular}{|lrrrrrr|}
\hline Taxon & \multicolumn{7}{c|}{ Date (Month/Day) } \\
& $2 / 12$ & $3 / 21$ & $4 / 16$ & $7 / 25$ & $7 / 31$ & $11 / 25$ \\
& & & & & & \\
GSB & & & & & \\
Copepod nauplii & 83.5 & 48.1 & 617.8 & 423.8 & 163.5 & 31.1 \\
Polychaete larvae & 0.0 & 0.0 & 38.8 & 35.8 & 8.5 & 0.2 \\
Barnacle larvae & 0.0 & 0.0 & 1.8 & 1.0 & 0.0 & 0.0 \\
Tintinnids & 0.2 & 0.0 & 0.0 & 236.0 & 110.5 & 0.8 \\
& $5 / 20$ & $6 / 17$ & $7 / 17$ & $7 / 22$ & & \\
& & & & & & \\
PB & & & & & \\
Copepod nauplii & 49.5 & 14.2 & 19.9 & 18.0 & & \\
Polychaetr larvae & 3.4 & 0.3 & 0.6 & 4.2 & & \\
Barnacle lavad & 57.4 & 1.3 & 0.0 & 0.1 & & \\
Tintinnids & 0.2 & 0.0 & 0.0 & 0.0 & & \\
\hline
\end{tabular}

Table 2. Dependence of the net growth coefficient of ciliate populations $\left(\mathrm{d}^{-1}\right)$ on ambient physical factors $\left({ }^{\circ} \mathrm{C}\right.$ and $\%$, primary productivity ( $\mathrm{mg} \mathrm{C} \mathrm{m} \mathrm{C}^{-2} \mathrm{~h}^{-1}$ ), and brown tide concentration $\left(\times 10^{3}\right.$ cells $\left.\mathrm{ml}^{-1}\right)$ in Long Island bays determined from multiple regression analysis. The model was significant ( $\mathrm{df}=$ $5.14, F=15.047, p<0.001$ ), and explained $68.0 \%$ of the variance in the net growth coefficient

\begin{tabular}{|lcrr|}
\hline Variable & $\begin{array}{c}\text { Partial regression } \\
\text { coefficient }\end{array}$ & $F$ & $p$ \\
& $(\mathrm{df}=1,14)$ & \\
\hline Intercept & 0.807 & & \\
Temperature & 0.077 & 10.914 & $0.005<\mathrm{p}<0.01$ \\
Salinity & -0.051 & 0.291 & $0.5<\mathrm{p}<0.75$ \\
$\begin{array}{l}\text { Primary productivity } \\
\quad \text { Total }\end{array}$ & 0.012 & 1.547 & $0.1<\mathrm{p}<0.25$ \\
$\quad<10 \mu \mathrm{mm}$ & -0.017 & 3.099 & $0.1<\mathrm{p}<0.25$ \\
$\begin{array}{l}\text { Brown tide } \\
\text { concentration }\end{array}$ & -0.192 & 49.792 & $\mathrm{p}<0.001$ \\
\hline
\end{tabular}

חบ Tintinnids

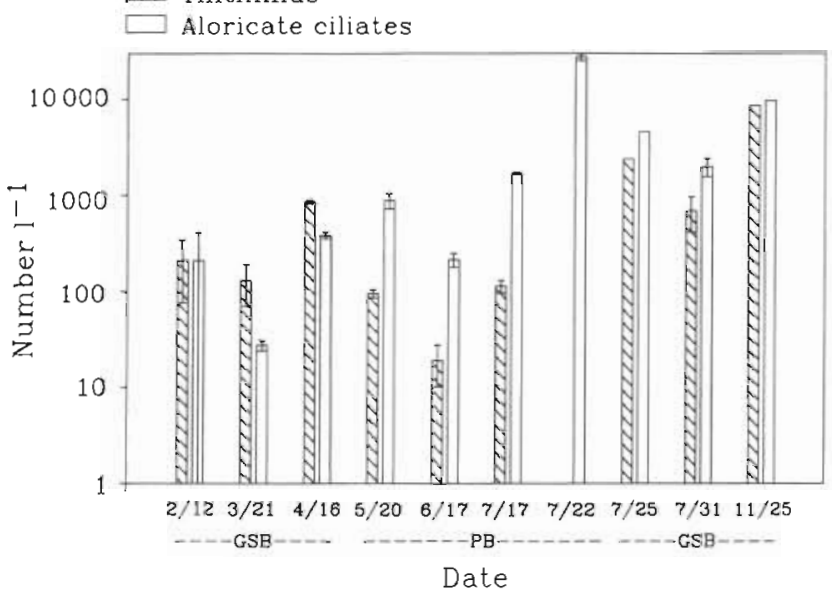

Fig. 7. Abundance (mean \pm range, $n=2$ ) of tintinnids and aloricate ciliates 20 to $64 \mu \mathrm{m}$

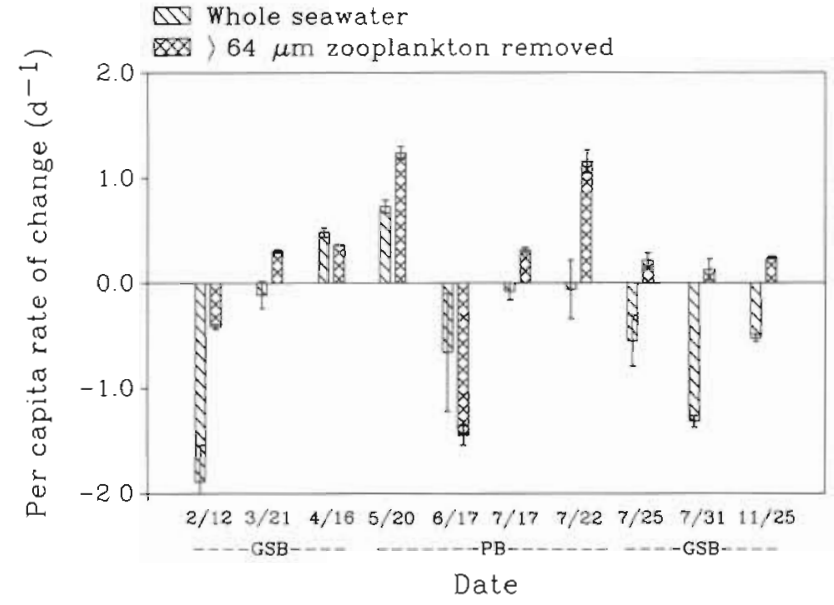

Fig. 8. Per capita rate of change (mean \pm range, $n=2$ ) of ciliate populations determined in microcosm experiments. The net growth coefficient of the ciliate population is shown as the $>64 \mu \mathrm{m}$ zooplankton removal treatment

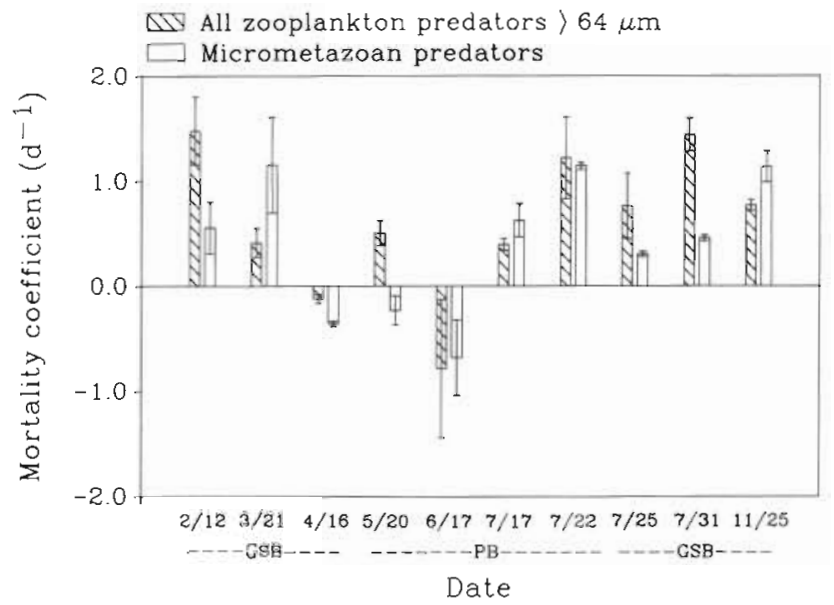

Fig. 9. Mortality coefficient of ciliate populations (mean \pm range, $\mathrm{n}=2$ ) from all larger zooplankton (>64 $\mu \mathrm{m}$ ) or only micrometazoa determined in microcosm experiments

by phytoplankton food resources under non-bloom conditions.

The mortality coefficient of ciliates $\left(\mathrm{d}^{-1}\right.$; i.e. zooplankton predation coefficient) from total metazoan zooplankton was positive on all sampling dates, except in April in GSB (mean $=-0.12 \mathrm{~d}^{-1}$ ), and during the peak of the brown tide in PB $\left(-1.445 \mathrm{~d}^{-1}\right.$; Fig. 9). However, the presence of Aureococcus anophagefferens cells was shown not to be a significant factor in contributing to variation in mortality rate (Table 3). Mortality rates were negatively correlated with $>10 \mu \mathrm{m}$ primary production, and positively related to total primary production, the majority of which is mostly $<5 \mu \mathrm{m}$. During April, when a negative mortality rate 
Table 3. Dependence of the mortality coefficient of ciliates $\left(d^{-1}\right)$ on water temperature $\left({ }^{\circ} \mathrm{C}\right)$, total zooplankton abundance (number $\mathrm{I}^{-1}$ ), primary productivity ( $\mathrm{mg} \mathrm{C}^{-2} \mathrm{~h}^{-1}$ ), brown tide concentration $\left(\times 10^{5}\right.$ cells $\left.\mathrm{ml}^{-1}\right)$, and the initial concentration of ciliates (number $\mathrm{I}^{-1}$ ) determined from multiple regression analysis. The model was significant $(\mathrm{df}=6,13 ; F=7.496 ; 0.001$ $<p<0.005$ ), and explained $77.6 \%$ of the variance in the mortality coefficient

\begin{tabular}{|lrrr|}
\hline Variable & $\begin{array}{c}\text { Partial regression } \\
\text { coefficient }\end{array}$ & $F$ & $p$ \\
& $(\mathrm{df}=1,13)$ & \\
\hline Intercept & 1.535 & & \\
$\begin{array}{l}\text { Temperature } \\
\text { Zooplank, abund. }\end{array}$ & -0.062 & 5.591 & $0.025<\mathrm{p}<0.05$ \\
$\begin{array}{l}\text { Primary productivity } \\
\text { Total }\end{array}$ & 0.007 & 11.691 & $0.50<\mathrm{p}<0.75$ \\
$\quad \begin{array}{l}>10 \mu \mathrm{m} \\
\text { Brown tide } \\
\text { concentration }\end{array}$ & -0.046 & 8.873 & $0.001<\mathrm{p}<0.005$ \\
$\begin{array}{l}\text { Initial ciliate } \\
\text { abundance }\end{array}$ & 0.019 & 0.122 & $0.50<\mathrm{p}<0.75$ \\
\hline
\end{tabular}

Table 4. Dependence of the mortality coefficient of ciliates $\left(d^{-1}\right)$ on physical and biological variables as in Table 3 , but excluding data during the peak of the brown tide on $6 / 17$ The model was significant $(\mathrm{df}=6.11 ; F=4.723 ; 0.01<\mathrm{p}<0.025$ ) and explaned $72.0 \%$ of the variance in the mortality coefficient

\begin{tabular}{|c|c|c|c|}
\hline Variable & $\begin{array}{c}\text { Partial regression } \\
\text { coefficient }\end{array}$ & $\begin{array}{l}n \quad F \\
(\mathrm{df}=1,11)\end{array}$ & $\mathrm{p}$ \\
\hline Intercept & 1.531 & & \\
\hline Temperature & -0.065 & 5.351 & $0.025<p<0.05$ \\
\hline Zooplank. abu & ind. -0.001 & 2.075 & $0.10<p<0.25$ \\
\hline \multicolumn{4}{|c|}{ Primary productivity } \\
\hline Total & 0.007 & 11.980 & $0.005<\mathrm{p}<0.010$ \\
\hline$>10 \mid . \mathrm{m}$ & -0.045 & 8.663 & $0.01<\mathrm{p}<0.025$ \\
\hline $\begin{array}{l}\text { Brown tide } \\
\text { concentration }\end{array}$ & 0.034 & 0.102 & $p>0.75$ \\
\hline $\begin{array}{l}\text { Initial ciliate } \\
\text { abundance }\end{array}$ & 0.057 & 8.059 & $0.01<p<0.025$ \\
\hline
\end{tabular}

was measured, the rate of primary production in the $>10 \mu \mathrm{m}$ size fraction was higher than at any other time in GSB, and the same was also true in PB during the peak of the brown tide. Other variables that also explained variation in ciliate mortality rate included water temperature and the initial concentration of ciliates. The negative correlation between mortality and primary productivity by larger phytoplankton was not a spurious result due to the inclusion of data during the brown tide peak. An additional multiple regression analysis that excluded these data did not significantly change the statistical outcome for any independent variables (Table 4 ).

Our results indicate that both mesozooplankton and micrometazoa exert a significant impact on ciliate pop- ulation growth. The average mortality coefficient of ciliates due to micrometazoa was on average $67.8 \%$ of the total mortality from all zooplankton. There was no significant difference among the mortality coefficients from the 2 zooplankton treatments (t-test for paired comparisons of mortality coefficients on each date; $\mathrm{df}=$ $19, t=1.23,0.2<\mathrm{p}<0.4)$

\section{Zooplankton grazing and predation}

In general, mesozooplankton had a higher average carbon consumption rate per individual in winter/ spring than in summer (Table 5), although averages were not significantly different $10.408 \pm 0.53795 \%$ confidence interval, $\mathrm{Cl}$, and $0.036 \pm 0.061 \mu \mathrm{g} \mathrm{C}$ ind. ${ }^{-1}$ $\mathrm{h}^{-1}$ including brown tide dates, respectively). The highest phytoplankton carbon consumption by mesozooplankton in summer occurred on $7 / 17$ during the brown tide, $0.161 \mu \mathrm{g} \mathrm{C}$ ind. ${ }^{-1} \mathrm{~h}^{-1}$, and in winter/spring on $3 / 21$ (1.449 $\left.\mu \mathrm{g} \mathrm{Cind} .^{-1} \mathrm{~h}^{-1}\right)$. In contrast, a seasonally based trend in phytoplankton carbon consumption by micrometazoa was not evident $(0.056 \pm 0.051$ and 0.028 $\pm 0.028 \mu \mathrm{g} \mathrm{C}$ ind.$^{-1} \mathrm{~h}^{-1}$ for winter/spring and summer, respectively).

Dietary trends in carbon ingestion showed that mesozooplankton obtained a smaller percentage of their diet from phytoplankton and more from ciliates Table 6) during summer compared to winter and spring, the 2 exceptions being during the decline of brown tide. In contrast, micrometazoa routinely obtained $>70 \%$ of their carbon intake from phytoplankton except during the decline of the brown tide. On two dates in spring and summer, the micrometazoan community grazed $>40 \%$ of the total primary productivity $\left(\%=m g C\right.$ ingested $\mathrm{m}^{-2} \mathrm{~h}^{-1} / \mathrm{mg} \mathrm{C}$ produced $\mathrm{m}^{-2} \mathrm{~h}^{-1}$, depth-integrated rates $\times 100 ;$ Table 7 ), and this occurred when copepod nauplii were an abundant taxon (Table 1). The greatest grazing pressure by mesozooplankton was found in winter and spring when $\geq 15 \%$ of total depth-integrated primary productivity was consumed.

Throughout the year, adult copepods had a higher clearance rate $\left(\mathrm{ml}\right.$ ind. ${ }^{-1} \mathrm{~d}^{-1}$ determined from addition experiments; Fig. 10) on ciliates compared to the average rate on phytoplankton (Fig. 11; paired $t$-test for differences between means on each sampling date; $\mathrm{df}=9$, $t=2.425,0.02<\mathrm{p}<0.05$ ). For a conservative comparision, we calculated zooplankton clearance rates on phytoplankton by assuming that negative rates were equal to 0 (Fig. 11). Two points for micrometazoan clearance were excluded from the data because they were more than an order of magnitude higher than other rates and were deemed to be outliers (DixonMassey test; Sokal \& Rohlf $1981 ; 427.1 \mathrm{ml}^{\text {ind }} .^{-1} \mathrm{~d}^{-1}$ 
Table 5. Carbon ingested ( $\mu \mathrm{g} \mathrm{C}$ ind..$^{-1} \mathrm{~h}^{-1}$; mean $\pm 1 \mathrm{SE}, \mathrm{n}=4$ ) by mesozooplankton $(\mathrm{M})$ and micrometazoa (m) from 4 size fractions of the phytoplankton community. Total carbon ingestion does not always equal the summation of all fractions due to rounding errors. Radiolabeled, laboratory cultured microalgae were used as tracers of size-selective grazing; $<5 \mu \mathrm{m}$ diameter: Nan-

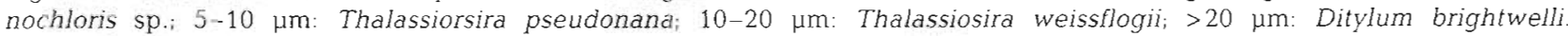
Negative ingestion rates are shown as 0 . Brown tide dates in West Neck Bay, Peconic Bays system are noted by

\begin{tabular}{|c|c|c|c|c|c|c|}
\hline \multirow[t]{2}{*}{ Date } & & \multicolumn{5}{|c|}{ Phytoplankton size-fraction ( $\mu \mathrm{m}$ diameter) } \\
\hline & & $<5$ & $\bar{j}-10$ & $10-20$ & $>20$ & Total \\
\hline $2 / 12$ & $\begin{array}{l}\mathrm{M} \\
\mathrm{m}\end{array}$ & $\begin{array}{l}0.026(0.012) \\
0.005(0.003)\end{array}$ & $\begin{array}{l}0.009(0.003) \\
0.002(0.003)\end{array}$ & $\begin{array}{l}0.004(0.005) \\
0.003(0.001)\end{array}$ & $\begin{array}{r}0.005(0.003) \\
<0.001(0.003)\end{array}$ & $\begin{array}{l}0.043 \\
0.011\end{array}$ \\
\hline $3 / 21$ & $\begin{array}{l}M \\
m\end{array}$ & $\begin{array}{l}1.339(0.293) \\
0.067(0.017)\end{array}$ & $\begin{array}{l}0.075(0.027) \\
0.004(<0.001)\end{array}$ & $\begin{array}{l}0.030(0.010) \\
0.003(<0.001)\end{array}$ & $\begin{array}{l}0.005(0.006) \\
0.001(<0.001)\end{array}$ & $\begin{array}{l}1.449 \\
0.075\end{array}$ \\
\hline $4 / 16$ & $\begin{array}{l}M \\
m\end{array}$ & $\begin{array}{l}0.023(0.017) \\
0.024(0.024)\end{array}$ & $\begin{array}{c}0.009(0.008) \\
<0.001(<0.001)\end{array}$ & $\begin{array}{l}0.017(0.010) \\
0.017(0.011)\end{array}$ & $\begin{array}{l}0.011(0.007) \\
0.009(0.005)\end{array}$ & $\begin{array}{l}0.060 \\
0.051\end{array}$ \\
\hline $5 / 21$ & $\begin{array}{l}M \\
\mathrm{~m}\end{array}$ & $\begin{array}{c}0.002(0.001) \\
<0.001(<0.001)\end{array}$ & $\begin{array}{l}0 \\
0\end{array}$ & $\begin{array}{c}0.004(0.002) \\
<0.001(<0.001)\end{array}$ & $\begin{array}{l}0 \\
0\end{array}$ & $\begin{array}{r}0.007 \\
<0.001\end{array}$ \\
\hline $6 / 17$ & $\begin{array}{l}M \\
m\end{array}$ & $\begin{array}{l}0 \\
0\end{array}$ & $\begin{array}{c}0 \\
<0.001\end{array}(<0.001)$ & $\begin{array}{c}<0.001(<0.001) \\
0\end{array}$ & $\begin{array}{l}0 \\
0\end{array}$ & $\begin{array}{l}<0.001 \\
<0.001\end{array}$ \\
\hline$\cdot 7 / 17$ & $\begin{array}{l}\mathrm{M} \\
\mathrm{m}\end{array}$ & $\begin{array}{c}0.159(0.169) \\
0\end{array}$ & $\begin{array}{l}<0.001(<0.001) \\
<0.001 .(<0.001)\end{array}$ & $\begin{array}{r}<0.001(<0.001) \\
0.001(<0.001)\end{array}$ & $\begin{array}{l}0.001(0.008) \\
0.002(0.001)\end{array}$ & $\begin{array}{l}0.161 \\
0.002\end{array}$ \\
\hline$\cdot 7 / 22$ & $\begin{array}{l}M \\
m\end{array}$ & $\begin{array}{l}0 \\
0\end{array}$ & $\begin{array}{c}0 \\
0.011(0.009)\end{array}$ & $\begin{array}{c}<0.001(<0.001) \\
0\end{array}$ & $\begin{array}{c}0 \\
0.025(0.021)\end{array}$ & $\begin{array}{r}<0.001 \\
0.036\end{array}$ \\
\hline $7 / 25$ & $\begin{array}{l}M \\
m\end{array}$ & $\begin{array}{l}0.007(0.063) \\
0.047(0.046)\end{array}$ & $\begin{array}{c}<0.001(<0.001) \\
0.006(0.001)\end{array}$ & $\begin{array}{l}<0.001(<0.001) \\
<0.001 \quad(<0.001)\end{array}$ & $\begin{array}{c}0 \\
0.025(0.003)\end{array}$ & $\begin{array}{l}0.007 \\
0.078\end{array}$ \\
\hline $7 / 31$ & $\begin{array}{l}M \\
\mathrm{~m}\end{array}$ & $\begin{array}{l}0.003(0.003) \\
0.002(0.001)\end{array}$ & $\begin{array}{l}<0.001(<0.001) \\
<0.001(<0.001)\end{array}$ & $\begin{array}{l}0.002(0.001) \\
0.004(<0.001)\end{array}$ & $\begin{array}{l}0.006(0.003) \\
0018(0.004)\end{array}$ & $\begin{array}{l}0.012 \\
0.023\end{array}$ \\
\hline $11 / 25$ & $\begin{array}{l}M \\
m\end{array}$ & $\begin{array}{l}0.465(0.211) \\
0.054(0.078)\end{array}$ & $\begin{array}{l}0.005(0.003) \\
0.004(0.002)\end{array}$ & $\begin{array}{l}0.011(0.003) \\
0.004(0.001)\end{array}$ & $\begin{array}{c}0 \\
0.084(0.090)\end{array}$ & $\begin{array}{l}0.480 \\
0.145\end{array}$ \\
\hline
\end{tabular}

with Thalassiosira pseudonana as a tracer on 3/21 and $458.7 \mathrm{ml}$ ind..$^{-1} \mathrm{~d}^{-1}$ with Nannochloris sp. on 7/22). On only 1 sampling date $(7 / 22)$ was the clearance rate on ciliates less than that on phytoplankton for adult copepods. For micrometazoa, however, the dietary importance of the larger ciliates is less certain. In the grazer addition experiments, naupliar clearance rates on ciliates were positive for only $50 \%$ of the experimental dates (Fig. 10). Clearance rates of micrometazoa were not effected by prey type (paired $t$-test; $\mathrm{df}=9, t=$ $0.910, p>0.2)$
Table 6. Total carbon ingested ( $\mu \mathrm{g} \mathrm{C}$ ind. $\left.{ }^{-1} \mathrm{~h}^{-1}\right)(\mathrm{I})$ and percentage carbon intake from phytoplankton (PP) and ciliates (C) for total mesozooplankton and micrometazoa

\begin{tabular}{|ccrrrrrrr|}
\hline \multirow{2}{*}{ Bay } & Date & \multicolumn{4}{c}{ Mesozooplankton } & \multicolumn{3}{c|}{ Micrometazoa } \\
& & I & PP & C & I & PP & C \\
\hline GSB & $2 / 12$ & 0.047 & 92.1 & 7.2 & 0.011 & 97.6 & 2.4 \\
& $3 / 21$ & 1.451 & 99.9 & 0.1 & 0.075 & 99.4 & 0.6 \\
& $4 / 16$ & 0.085 & 70.7 & 29.3 & 0.051 & 100.0 & 0.0 \\
& & & & & & & \\
PB & $5 / 20$ & 0.015 & 43.7 & 56.3 & $<0.001$ & 63.4 & 36.6 \\
& $6 / 17$ & 0.004 & 8.6 & 91.4 & $<0.001$ & 100.0 & 0.0 \\
& $7 / 17$ & 0.171 & 93.6 & 5.4 & 0.007 & 37.3 & 62.7 \\
& $7 / 22$ & $<0.001$ & 100.0 & 0.0 & 0.400 & 9.0 & 91.0 \\
GSB & $7 / 25$ & 0.071 & 10.1 & 89.9 & 0.109 & 71.1 & 28.9 \\
& $7 / 31$ & 0.037 & 32.7 & 67.3 & 0.024 & 98.3 & 1.7 \\
& $11 / 25$ & 0.550 & 87.5 & 12.5 & 0.266 & 54.6 & 45.4 \\
& & & & & & & \\
\hline
\end{tabular}

\section{Copepod egg production and hatching success}

Copepod egg production during summer (i.e. by Acartia tonsa) was limited by food, but this was not true in winter or spring (i.e. by $A$. hudsonica; Fig. 12). This was shown by the significant effect of sampling date $\times$ food treatment (ambient or enriched) on egg production rate $\left[\log (\right.$ number +1$)$ female $\mathrm{f}^{-1} \mathrm{~d}^{-1}$; 2-way ANOVA Af $_{i}=6,48, F=4.74, p<$ $0.001]$. Egg production rate also increased significantly during the summer ( $\mathrm{df}=6,48$, $F=60.44, \mathrm{p}<0.0001$ for sampling date effect; $\mathrm{df}=1.48, F=2.29, \mathrm{p}=0.14$ for food treatment effect)

Under ambient food conditions, water temperature did not correlate with egg produc- 
Table 7. Total depth-integrated carbon ingested $\left(\mathrm{mg} \mathrm{C} \mathrm{m}{ }^{-2}\right.$ $\left.h{ }^{\prime}\right)$ (I) and percentage of total depth-integrated primary production consumed by mesozooplankton and micrometazoa

\begin{tabular}{|c|c|c|c|c|c|}
\hline \multirow[t]{2}{*}{ Bay } & \multirow[t]{2}{*}{ Date } & \multicolumn{2}{|c|}{ Mesozooplankton } & \multicolumn{2}{|c|}{ Micrometazoa } \\
\hline & & I & $\%$ & I & $\%$ \\
\hline \multirow[t]{3}{*}{ GSB } & $2 / 12$ & 2.638 & 14.9 & 2.197 & 12.4 \\
\hline & $3 / 21$ & 6.086 & 24.5 & 5.627 & 22.6 \\
\hline & $4 / 16$ & 4.952 & 5.1 & 50.371 & 52.3 \\
\hline \multirow[t]{4}{*}{ PB } & $5 / 20$ & 0.047 & $<0.1$ & 0.051 & $<0.1$ \\
\hline & $6 / 17$ & 0.003 & $<0.01$ & $<0.001$ & $<0.001$ \\
\hline & $7 / 17$ & 1.697 & 2.8 & 0.074 & 0.1 \\
\hline & $7 / 22$ & $<0.001$ & $<0.001$ & 2.570 & 2.0 \\
\hline \multirow[t]{3}{*}{ GSB } & $7 / 25$ & 6.529 & 3.9 & 73.865 & 44.2 \\
\hline & $7 / 31$ & 4.525 & 1.4 & 9.974 & 3.1 \\
\hline & $11 / 25$ & 12.524 & 29.5 & 7.227 & 17.0 \\
\hline
\end{tabular}

tion rate (Multiple Regression analysis; Table 8 ). However, the production of ciliate food resources, as measured by their net growth coefficient, was directly related to copepod reproduction. The cell concentration of Aureococcus anophagefferens was negatively correlated to egg production rate, and likely reflected the fact that ciliate growth and $A$. anophagefferens cell concentration were negatively correlated (Table 2). All remaining environmental variables, including copepod species and total and $>10 \mu \mathrm{m}$ depth-integrated primary productivity, did not correlate to egg production rate

Egg hatching success of copepod eggs produced under ambient food conditions remained high throughout the study (>75\%; Fig. 13), although there was an effect of sampling date $(\mathrm{R} \times \mathrm{C}$ test of independence, $\mathrm{df}=5, G=50.081, \mathrm{p}>0.001$. Variances in the

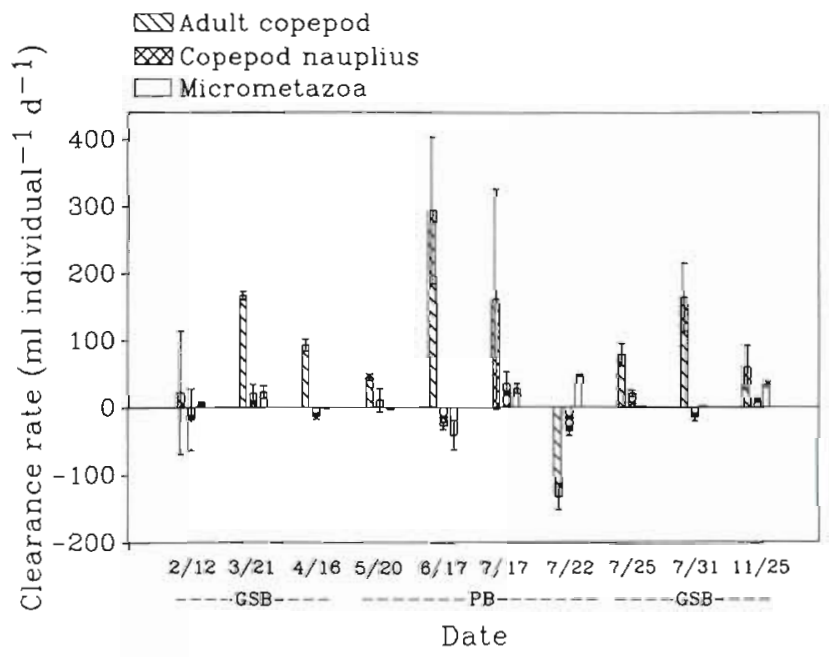

Fig. 10. Clearance rate (mean \pm range, $n=2$ ) of zooplankton predators (copepod adults, copepod nauplii, and natural assemblages of micrometazoa) on ciliates $\leq 64 \mu \mathrm{m}$

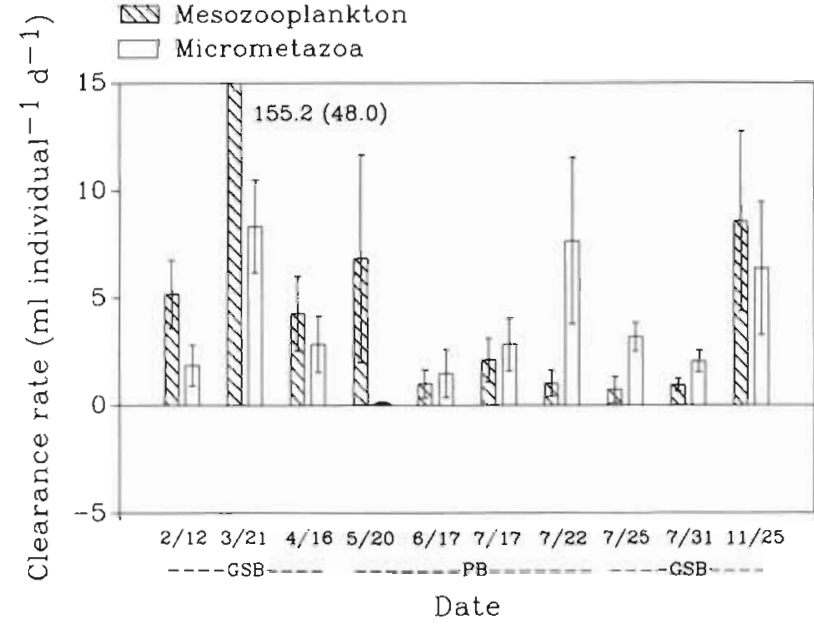

Fig. 11. Average clearance rate $( \pm 1 \mathrm{SE}$, generally, $n=16$ for all size fraction clearance rates) of mesozooplankton and micrometazoa on the total phytoplankton community

data sets were not normally distributed with an arcsine transformation, and thus a non-parametric test was necessary; Sokal \& Rohlf 1981). The lowest success occurred during the winter months.

\section{Copepod development rate and survival with brown tide}

Naupliar and copepodite survival were not affected by the addition of either Thalassiosira pseudonana or brown tide cells to ambient seawater compared to ambient conditions. Survival of copepods with only brown tide cells for food was the same as in autoclaved seawater (Fig. 14). In suspension of only brown tide

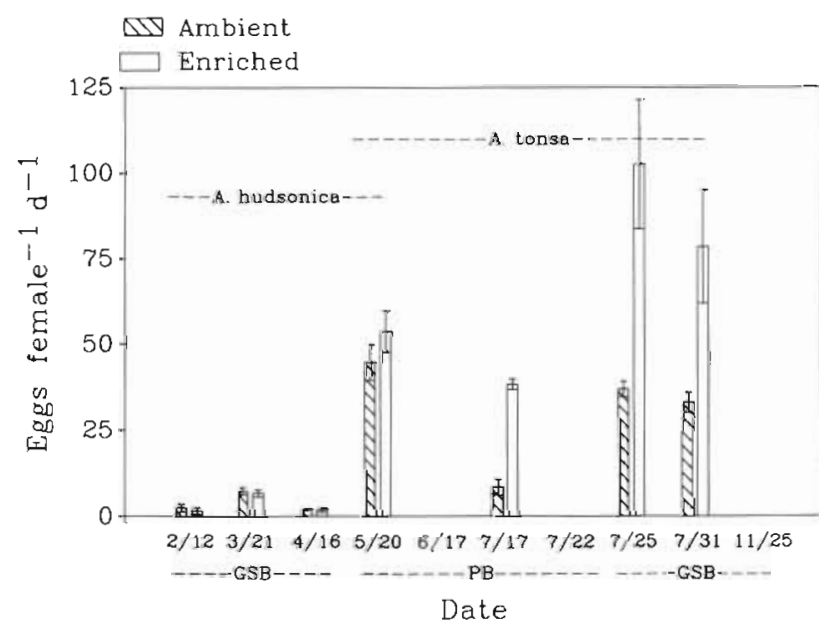

Fig. 12. Mean egg production rate ( $\pm 1 \mathrm{SE}, \mathrm{n}=3$ to 6 ) of $A c a r-$ tia spp. under ambient and enriched food conditions. Experiments were not conducted on $6 / 17,7 / 22$ or $11 / 25$ 
Table 8. Dependence of ambient egg production rate (log number +1 copepod $\left.^{-1} \mathrm{~d}^{-1}\right)$ on water temperature $\left({ }^{\circ} \mathrm{C}\right)$, copepod species composition, primary productivity $\left(\mathrm{mg} \mathrm{C} \mathrm{m}^{-2} \mathrm{~h}^{-1}\right)$, brown tide concentration $\left(\times 10^{5}\right.$ cells $\left.\mathrm{ml}^{-1}\right)$, and the net growth coefficient of culates $\left(\mathrm{d}^{-1}\right)$ determined from multiple regression analysis. The model was significant $(\mathrm{df}=6,27 ; F=28.660$; $p<0.001)$ and explained $86.4 \%$ of the variance in egg production rate

\begin{tabular}{|c|c|c|c|}
\hline Vanable & $\begin{array}{l}\text { artial regressior } \\
\text { coefficient }\end{array}$ & $\begin{array}{l}F \\
(\mathrm{df}=1,27)\end{array}$ & $\mathrm{p}$ \\
\hline Intercept & 0.521 & & \\
\hline Temperature & 0.047 & 0.633 & $0.25<p<0.50$ \\
\hline Copepod species & 0.306 & 0.169 & $0.50<p<0.75$ \\
\hline \multicolumn{4}{|c|}{ Primary productivity } \\
\hline Total & 0.002 & 1.256 & $0.25<p<0.50$ \\
\hline$>10 \mu \mathrm{m}$ & -0.048 & 3.088 & $0.05<p<0.10$ \\
\hline $\begin{array}{l}\text { Brown tide } \\
\text { concentration }\end{array}$ & -0.115 & 4.392 & $0.025<\mathrm{p}<0.05$ \\
\hline $\begin{array}{l}\text { Net growth coeffi } \\
\text { of ciliates }\end{array}$ & $\begin{array}{l}\text { fficient } \\
\quad 0.528\end{array}$ & 12.223 & $0.001<\mathrm{p}<0.005$ \\
\hline
\end{tabular}

Table 9. Mean ( $\pm 1 \mathrm{SE}$ ) development time (h) of Acartia hudsonica copepodites (CI to CIII) and Coullana canadensis nauphi (NI to $\mathrm{Cl}$ ) reared under 3 food treatments (AMB: ambient seawater; $A M B+3 \mathrm{H}$ : ambient seawater enriched with Thalassiosira pseudonana cells; and $\mathrm{AMB}+\mathrm{BT}$ : ambient seawater enriched with Aureococcus anophagefferens cells). Copepods did not complete development with only filtered seawater or brown tide cells

\begin{tabular}{|lccc|}
\hline Species & \multicolumn{3}{c}{ Treatment } \\
& AMB & AMB + 3H & AMB + BT \\
\hline A. hudsonica & & & \\
$\mathrm{n}$ & 8 & 10 & 12 \\
$x$ & 67.5 & 61.3 & 72.7 \\
$\mathrm{SE}$ & 3.3 & 1.5 & 5.5 \\
C. canadensis & & & \\
$\mathrm{n}$ & 13 & 15 & 14 \\
$\mathrm{x}$ & 112.1 & 105.2 & 116.2 \\
$\mathrm{SE}$ & 1.8 & 1.7 & 1.7 \\
& & & \\
\hline
\end{tabular}

cells or filtered seawater, nauplii and copepodites did not molt past NII or CII, respectively. Copepodite development rates were not significantly different among the 3 other food treatments (ambient, ambient + brown tide cells, ambient $+T$. pseudonana cells; 1 -way ANOVA, $d f=2,27, F=1.33, p=0.28$; Table 9), but naupliar development rate was faster with $3 \mathrm{H}$ additions compared to ambient or brown tide addition treatments (ANOVA, df $=2,39, F=10.95, p=0.0002$, and Tukey-Kramer unplanned comparisons among means at 0.05 level of significance). Thus, the brown tide did not contribute to or hinder growth and survival of copepods at lower bloom concentrations (i.e. $5 \times 10^{5}$ cells $\mathrm{ml}^{-1}$ ) in the presence of alternate food sources.

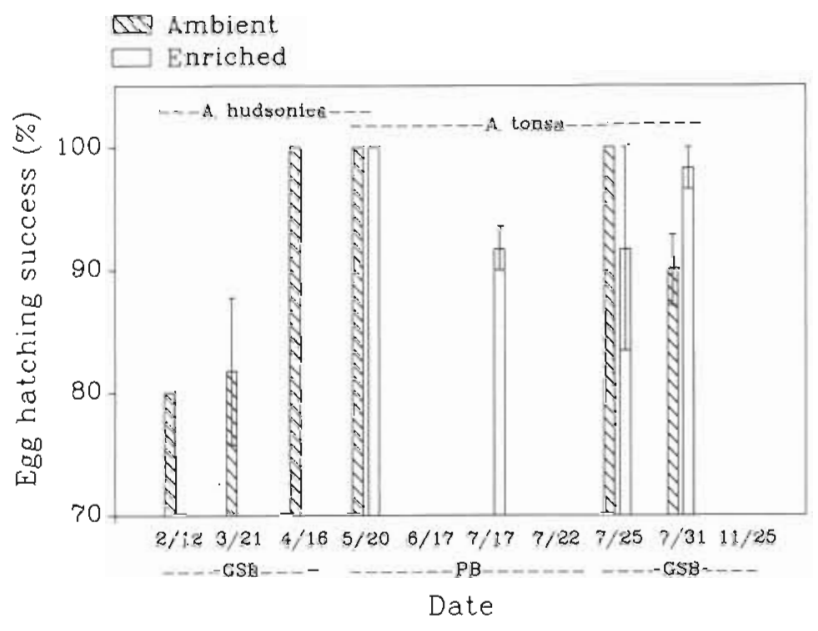

Fig. 13. Mean hatching success ( $\pm 1 \mathrm{SE}, n=3$ to 6 ) of copepod eggs produced under ambient and enriched food conditions by Acartia spp
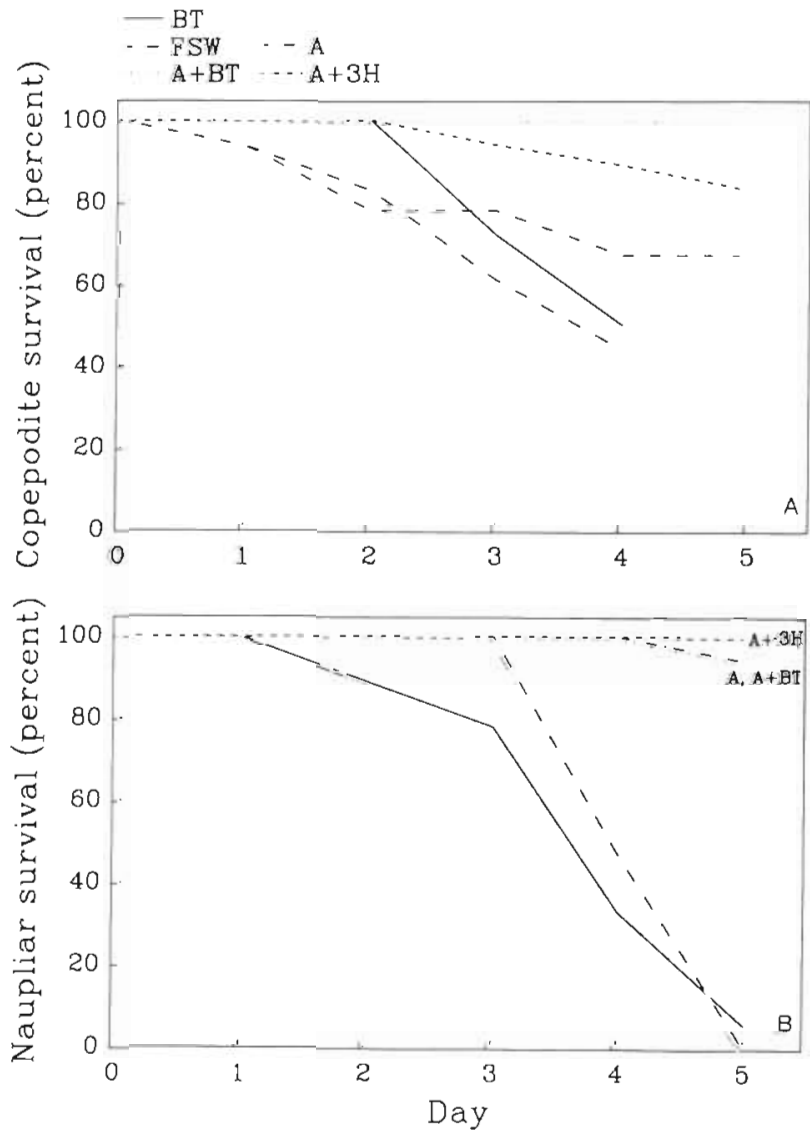

Fig. 14. Percentage survival of laboratory-reared copepods, (A) Acartia hudsonica (NVI to CIII) and (B) Coullana canadensis ( $\mathrm{NI}$ to $\mathrm{CI}$ ), reared under 16 and $20^{\circ} \mathrm{C}$, respectively, and 5 food treatments (BT: brown tide cells only; FSW: filtered seawater; $A$ : ambient seawater; $A+B T$ : ambient plus brown tide cells; $\mathrm{A}+3 \mathrm{H}$ : ambient plus Thalassiosira pseudonana cells) 


\section{DISCUSSION}

This study supports the idea that predation on protozoa is critical for copepod production in summer when nannoplankton $<5 \mu \mathrm{m}$ dominate the phytoplankton. Although larger nannoplankton and netplankton $(>20 \mu \mathrm{m})$ never dominated the plankton in terms of either productivity or biomass, phytoplankton was a major source of carbon nutrition for copepods in winter and spring. Holoplanktonic and meroplanktonic larvae, however, almost always utilized phytoplankton to obtain the majority of their carbon ration. The carbon ration accrued from ciliates by micrometazoa may be a passive consequence of feeding on phytoplankton as no prey-dependent difference in clearance rates was found. In contrast, adult copepods routinely had a higher clearance rate on ciliates compared to phytoplankton throughout the year.

Laboratory studies by Jonsson \& Tiselius (1990) showed that Acartia tonsa adults switched between suspension and raptorial feeding depending on the concentration of phytoplankton. Acartia spent more time in suspension feeding under high concentrations of the flagellate Rhodomonas baltica $(-8 \mu \mathrm{m}$ width, $13 \mu \mathrm{m}$ length) compared to low or moderate concentrations. Such a switch in feeding behavior could explain our field results which indicated that the mortality coefficient of ciliates from all zooplankton was inversely correlated with $>10 \mu \mathrm{m}$ primary productivity and positively related to total depth-integrated primary productivity (Fig. 9, Table 2). Necessary for this explanation would be the lack of response (detection?) by copepods to the high productivity rates of the $<5 \mu \mathrm{m}$ phytoplankton in summer, and hence raptorial feeding may predominate. However, a concomitant increase in adult copepod clearance rates (per individual) on ciliates in the summer was not obvious in our study (Fig. 10), except during the peak of the brown tide. Increased ciliate concentrations during the summer may have negated the necessity for increased time spent in raptorial feeding for copepods to increase their ration

Our finding that in GSB in summer, ciliates were more important than phytoplankton in mesozooplankton diets does not match studies in Chesapeake Bay. For Acartia tonsa, at least, over $80 \%$ of the carbon ingested was from phytoplankton in August compared to only $19 \%$ in May in Chesapeake Bay (White \& Roman 1992a). These differences could be due to variation among locations in the composition of phytoplankton, although a seasonal shift from diatoms to flagellates is also characteristic of Chesapeake Bay (Malone et al. 1988, cited by White \& Roman 1992b).

Few studies have measured feeding rates of meroplanktonic and holoplanktonic larvae and other micrometazoa on natural plankton despite the fact that their weight-specific ingestion rates may be 3 to 4 times higher than adults, and that numerically they are usually very important (e.g. Lonsdale \& Coull 1977. Turner 1982). Using other ${ }^{14} \mathrm{C}$ tracer techniques (i.e. Daro 1978, Roman \& Rublee 1981), Kim (1993) found that the micrometazoan community in the Peconic Bays system graze on average 0.3 to $10.0 \%$ of total depth-integrated primary productivity compared with 0.2 to $4.3 \%$ for mesozooplankton. In GSB in summer, we found that micrometazoa consume the greatest percentage of total depth-integrated primary productivity compared to mesozooplankton (Table 6). The impact of micrometazoan grazing was greatest when copepod nauplii were an abundant taxon (i.e. 4/16 and 7/25; Table 1). Thus, these results agree with studies in the Chesapeake Bay (White \& Roman 1992b) that showed copepod nauplii often accounted for a large proportion of the total zooplankton grazing, and removed up to $50 \%$ of the total depth-integrated primary production in summer.

Zooplankton predation on a major nannoplankton consumer, the ciliates (Capriulo \& Carpenter 1980, Verity 1985, Sherr et al. 1991, Pierce \& Turner 1992 and references therein, Turner \& Granéli 1992), may contribute to the dominance of small phytoplankton in GSB, particularly in summer (Kim 1993). And although not specifically studied herein, we propose that mesozooplankton predation on micrometazoa, especially copepod nauplii (Lonsdale et al. 1979), could at times also have a 'cascading' (sensu Carpenter et al. 1987) influence on the phytoplankton community. We have shown herein that micrometazoa are important grazers of phytoplankton in Long Island bays, and it is known that copepod nauplii are prey for some adult copepods (e.g. Landry 1981). Thus, copepod nauplii likely serve as an additional link between primary productivity and mesozooplankton productivity in Long Island bays. As an example, depending on naupliar species and stage, adult Acartia tonsa may consume between 1.4 to 8.4 nauplii $\mathrm{d}^{-1}$ at a concentration ranging from $\sim 50$ to 300 prey $\mathrm{l}^{-1}$ (Lonsdale et al. 1979). Thus, it is possible that mesozooplankton could obtain up to an additional $0.015 \mu \mathrm{g} \mathrm{C}$ ind.$^{-1} \mathrm{~h}^{-1}$ from copepod nauplii, which is about 11 to $29 \%$ of that obtained from ciliate predation in summer (i.e. $7 / 25$ and 7/31). (We used the dry weight of Acartia clausi NV and NVI, $0.1 \mu \mathrm{g}$ (Marshall 1973), and assumed a carbon equivalent of $41.6 \%$ of the dry weight (Beers 1966) to estimate naupliar carbon content.] Naupliar predation by mesozooplankton may also be an important trophic link between primary productivity and copepod productivity in the Chesapeake Bay because nauplii also consume a significant fraction of the primary productivity (White \& Roman 1992b). 
Our grazing experiments were conducted for $7 \mathrm{~min}$ to minimize error from carbon recycling processes. Extrapolation of these short-term experiments to daily rates may not be appropriate given that zooplankton can exhibit diel variation in grazing activity. Roman et al. (1988) found that coastal copepods often showed higher feeding at night and that oceanic forms sometimes had higher feeding rates during the day. Mesozooplankton clearance rates on phytoplankton that we measured using radiolabeled algae were similar to Louisiana (USA) field populations of Acartia tonsa determined from gut pigment analysis (Gifford \& Dagg 1991) when the exceptionally high mean for $3 / 21$ (155.2 $\mathrm{ml} \mathrm{ind}^{-1} \mathrm{~d}^{-1}$; Fig. 11) is excluded from the data set [yearly average on all algal species $=3.4( \pm 1.9$ $95 \% \mathrm{Cl}$ ) $\mathrm{ml}$ ind..$^{-1} \mathrm{~d}^{-1}$ compared to $3.6 \mathrm{ml}$ ind. ${ }^{-1} \mathrm{~d}^{-1}$ respectively]. Including the $3 / 21$ clearance rate data also resulted in no significant difference among the studies $(18.6 \pm 29.895 \% \mathrm{CI})$. Also, total carbon ingestion rates of phytoplankton had similar seasonally based trends. For Long Island bays, ingestion rates averaged $0.9 \mu \mathrm{g} \mathrm{C}$ ind ${ }^{-1} \mathrm{~d}^{-1}$ in summer (i.e. primarily A. tonsa) and $9.8 \mu \mathrm{g} \mathrm{C}$ ind , $^{-1} \mathrm{~d}^{-1}$ in winter/spring ( $A$. hudsonica), and in Louisiana, 1.9 and $4.7 \mu \mathrm{g} \mathrm{C}$ copepod $\mathrm{d}^{-1} \mathrm{~d}^{-1}$, respectively ( $A$. tonsa year-round). Limitations of the radiotracer technique for measuring zooplankton grazing, however, became apparent during the experiments conducted in $\mathrm{PB}$ during the brown tide. The negative clearance rates of micrometazoa on $<5 \mu \mathrm{m}$ microalgae at this time are attributed to an experimental artifact due to the large number of $N a n-$ nochloris sp. tracer cells retained on the $64 \mu \mathrm{m}$ sieve at the high experimental concentrations $120 \%$ of the $<5 \mu \mathrm{m}$ biomass; Lonsdale \& Cosper 1994) that masked any detectable feeding by the few micrometazoa (16.5 to $23.7 \mathrm{l}^{-1}$ ). Occassionally, relatively high values for the filtrate control were also obtained, and we can only speculate as to the cause. Variation in grazing rate estimates within a sampling date was likely due to variation in zooplankton density in the grazing chambers, especially when density was low (e.g on $3 / 21$ when the average mesozooplankton concentration was lowest, $2.8 \mathrm{l}^{-1}$ ).

In Long Island bays, mesozooplankton clearance rates on ciliates when Acartia tonsa was abundant were mostly comparable to other studies of copepods preying on natural assemblages of ciliates and/or other protists such as Euglenoid sp. (average $=25.2$ and $23.8 \mathrm{ml} \mathrm{copepod}^{-1} \mathrm{~d}^{-1}$; Gifford \& Dagg 1991, Kim \& Chang 1992, respectively). The clearance rates on ciliates in Long Island bays when $A$. hudsonica was dominant, however, were on average higher than those in a natural prey assemblage during a dinoflagellate bloom in another temperate bay $\left(4.8\right.$ to $9.6 \mathrm{ml}$ copepod $\mathrm{d}^{-1}$; Turner \& Anderson 1983). Mesozooplankton carbon ingestion rates of ciliates in Long Island bays match closely that found by Gifford \& Dagg (1991); average $=$ $0.4 \mu \mathrm{g} \mathrm{C}$ ind.$^{-1} \mathrm{~d}^{-1}$ in winter/spring, and $2.5 \mu \mathrm{g} \mathrm{C}$ ind ${ }^{-1}$ $\mathrm{d}^{-1}$ in summer/fall compared with 0.1 and $2.1 \mu \mathrm{g} \mathrm{C}$ copepod ${ }^{-1} \mathrm{~d}^{-1}$, respectively, for $A$. tonsa in Louisiana.

Mesozooplankton were found to have high ingestion rates on phytoplankton in the spring in Long Island bays and copepod egg production was not food limited, at least as measured by our food enrichment studies. Over the course of spring and summer, however, we found that egg production was not related to either tatal or $>10 \mu \mathrm{m}$ depth-integrated primary production, but to the net growth coefficient of ciliates. In Chesapeake Bay following the spring bloom, egg production by Acartia tonsa was also positively related to microzooplankton ( $>10 \mu \mathrm{m}$ ) (measured as carbon concentration), while no relationship to chl a concentration (total or $>10 \mu \mathrm{m}$ size fraction) was found despite substantial ingestion of phytoplankton (White \& Roman 1992a).

There have been numerous field studies that conclude that water temperature is a major factor controlling egg production rate in copepods (e.g. Durbin et al. 1992). Our result showing no relationship of copepod egg production to temperature is not particularly strong because we have limited data for each copepod species (i.e. Acartia hudsonica and A. tonsa). However, a significant positive effect of temperature on egg production rate was calculated when the net growth rate of ciliates was not included as an independent variable in the multiple regression analysis ( $\mathrm{df}=1,28, F=$ $18.080, p<0.001)$. White \& Roman (1992a) found that both water temperature and carbon concentration of microzooplankton, and not phytoplankton abundance, were the best indicators of $A$. tonsa reproductive potential in Chesapeake Bay'. Perhaps the correlation between water temperature and egg production rate found in some field studies may partially reflect the underlying relationship of water temperature effects on the production rate of ciliate populations (Table 2).

\section{Ciliate population dynamics}

Robertson (1983) suggested that tintinnid population growth would only be suppressed when adult copepod densities exceeded $10 \mathrm{I}^{-1}$ (also see Pierce \& Turner 1992). In GSB, at least, adult copepod populations routinely exceeded this concentration, ranging from 2.8 to $248 \mathrm{I}^{-1}$ (Fig. 6). Ciliate population growth, however, was also suppressed by micrometazoa predation that contributed on average $67.8 \%$ to the total daily mortality from all zooplankton. This substantial influence on ciliate population growth was found despite the fact that ciliates contributed only a small percentage, usu- 
ally $<30 \%$, to the daily carbon ration of micrometazoa. It is possible, however, that our measures of ciliate mortality from predation deviated from nature. For example, small-scale turbulence impacts the detection and/or contact rates of some predators and prey (e.g. Rothschild \& Osborn 1988), and turbulence effects may have been altered in the microcosms.

The net growth coefficient of ciliate populations that we measured in Long Island bays (Fig. 8) was always lower than during spring in a Massachusetts bay; 1.55 and $0.77 \mathrm{~d}^{-1}$ for an aloricate and large tintinnid. respectively (Stoecker et al. 1983). During the spring and summer in Long Island bays, however, the net growth coefficient of aloricate ciliates reached 1.17 to $1.31 \mathrm{~d}^{-1}(7 / 22$ and 5/20, respectively). Tintinnid growth rates, on the other hand, reached a maximum rate of only $0.35 \mathrm{~d}^{-1}$ found in early spring $(3 / 21)$.

\section{Brown tide effects on plankton trophic interactions}

This investigation shows the importance of ciliates in the diets of metazoan zooplankton, and provides insight into the manner in which blooms of Aureococcus anophagefferens may alter plankton dynamics. Previous studies on plankton dynamics in Long Island bays during brown tides have shown that grazing, measured with fluorescently labeled algae and bacteria, and growth of some species of protozod were not suppressed in the presence of a brown tide (PB and GSB; Caron et al. 1989), yet we found ciliate population growth to be negatively affected. It is noteworthy that the cell concentrations of $A$. anophagefferens under which Caron et al. conducted their laboratory and field investigations were lower $\left(1 \times 10^{6} \mathrm{cells} \mathrm{m}^{-1}\right.$ and $\sim 1 \times 10^{4}$ to $4 \times 10^{5}$ cells $\mathrm{ml}^{-1}$, respectively) than during our study on $6 / 17\left(1.46 \times 10^{6}\right.$ cells $\left.\mathrm{ml}^{-1}\right)$ when a negative growth rate of the ciliate population occurred (Fig. 8). We also found that the density of aloricate ciliates increased substantially from 6/17 to $7 / 22$ (230 to $27400 \mathrm{l}^{-1}$ ) during the decline of the brown tide (to $3 \times$ $10^{4}$ cells $\mathrm{ml}^{-1}$ ). Thus, these 2 studies are not inconsistent, but rather suggest a 'threshold' phenomenon in which microbial processes, especially protozoan grazing and production, continue over a wide range of cell concentrations of A. anophagefferens, and are disrupted only during peak bloom conditions (i.e. $>1 \times 10^{6}$ cells $\mathrm{ml}^{-1}$ ). This hypothesis is further supported by our laboratory findings on copepod growth and survival, which showed that at $5 \times 10^{5}$ cells $\mathrm{mI}^{-1}$ there were no detrimental effects of the brown tide if alternate food sources were available.

During 1985 and 1986, the bloom of Aureococcus anophagefferens did not appear to be associated with reduced copepod abundances in GSB (Duguay et al.
1989), and abundances were not unlike those we found during the 1991 non-bloom year For 1986, when extensive monitoring of the brown tide was conducted in GSB, the average concentration was $1.4 \times 10^{5}$ cells $\mathrm{ml}^{-1}$, and reached a peak of only 6 to $7 \times 10^{5}$ cells $\mathrm{ml}^{-1}$ (Nuzzi \& Waters 1989). Other phytoplankton such as Nannochloris sp., a likely food resource for many protozoa, also outnumbered $A$. anophagefferens. Thus, microbial processes likely remained intact, and allowed for normal levels of zooplankton productivity. Durbin \& Durbin (1989) also provide evidence that lower concentrations of brown tide cells are not especially detrimental to zooplankton production. They reported that Acartia tonsa weight, 'condition factor', and egg production rate during a brown tide $\left(7.6 \times 10^{5}\right.$ cells $\mathrm{ml}^{-1}$ ) in Narragansett Bay (Rhode Island, USA) were low, but not unlike those sometimes found in other non-bloom years. We found that egg production rates were significantly affected by the brown tide, but this observation (7/17) was made just after the brown tide had reached over $1 \times 10^{6}$ cells $\mathrm{ml}^{-1}$ on $7 / 14$ (Fig. 5) However, we cannot conclude from our limited sampling in 1991 that the lower summer density of PB zooplankton compared to GSB was due to brown tide cell concentration on 6/17 because these differences may be due to local differences, and we do not have estimates for West Neck Bay (PB) prior to the bloom.

\section{Conclusion}

This study has shown that the relative importance of phytoplankton and ciliates as prey differs among mesozooplankton and micrometazoa in Long Island bays. But, because their food resource niches are not mutually exclusive, and because micrometazoa comprise a major component all larger zooplankton, exploitative competition for ciliates is likely intense. particularly in the summer During summer, the mortality coefficient often exceeds the net growth coefficient of ciliates, and thus ciliates may be in short supply. The effects of competition for ciliates may be especially acute for mesozooplankton, and this hypothesis is supported by our finding that ambient food resources limited the production rate of copepod eggs during the summer months. We do not have similar evidence to determine the impact of food limitation on growth of micrometazoa. However, it is probable that food limitation effects under non-bloom conditions would be minimal on copepod naupliar or polychaete larval growth, as also found for ciliates, because phytoplankton is not in short supply, at least as measured by rates of primary productivity in Long Island bays. Future studies on the role of food limitation on zooplankton growth and survival rates will provide insight 
into the biological processes controlling recruitment in coastal bays. Measurements of food limitation in zooplankton will also enhance our understanding of the evolution and significance of life-history variation among marine invertebrate populations.

Acknowledgements. This research was funded by the New York State Living Marine Resources Institute and New York State Sea Grant College. Phytoplankton identifications were made by Dr Man Chang (visiting Scholar from the Korean Ocean Research and Development Institute). We appreciate the manuscipt review by Dr Gordon Taylor (Marine Sclences Research Center) and helpful comments of 3 anonymous reviewers. This is Contribution 1009 of the Marine Sciences Research Center.

\section{LITERATURE CITED}

Anderson DM, Kulis DM, Celta CM, Cosper EM (1989) Immunofluorescent detection of the brown tide organism, Aureococcus anophagefferens. In: Cosper EM, Bricelj VM, Carpenter EJ (eds) Novel phytoplankton blooms: causes and impacts of recurrent brown tides and other unusual blooms. Lecture notes on coastal and estuarine studies. Springer-Verlag, Berlin, p 213-228

Azam F, Fenchel T, Field JG, Gray JS, Meyer-Reil LA, Thingstad F (1983) The ecological role of water-column microbes in the sea. Mar Ecol Prog Ser 10:257-263

Beers JR (1966) Studies on the chemical composition of the major zooplankton groups in the Sargasso Sea. Limnol Oceanogr 11:520-528

Bruno SF, Staker RD, Shamma GM, Turner JT (1983) Primary productivity and phytoplankton size fraction dominance in a temperate North Atlantic estuary. Estuaries 6:200-211

Capriulo GM, Carpenter EJ (1980) Grazing by 35 to $202 \mu \mathrm{m} \mathrm{mi-}$ crozooplankton in Long Ts]and Sound. Mar Biol 56:319-326

Caron DA, Lim EL, Kunze H, Cosper EM, Anderson DM (1989) Trophic interactions between nano- and microzooplankton and the 'brown tide'. In: Cosper EM, Bricelj VM, Carpenter 1:I (eds) vord phytoplankton blooms: causes and impacts of recurrent brown tides and other unusual blooms Lecture notes on coastal and estuarine studies. Springer-Verlag, Berlin, p 265-294

Carpenter EJ, Brinkhuis BM, Capone DG (1991) Primary production and nitrogenous nutrients in Great South Bay. In: Schubel JR, Bell TM, Carter HH (eds) The Great South Bay. State University of New York Press, Albany, p 33-42

Carpenter SR, Kitchell JF, Hodgson JR, Cochran PA, Elser JJ, Elser MM, Lodge DM, Kretchmer D, He X (1987) Regulation of lake primary productivity by food web structure Ecology 68:1863-1876

Conover RJ (1982) Interrelationships between microzooplankton and other plankton organisms. Ann Inst Oceanogr, Paris 58(S):3146

Cosper EM, Carpenter EJ, Cottrell M (1989) Primary productivity and growth dynamics of the 'brown tide' in Long Island embayments. In: Cosper EM, Bricelj VM, Carpenter EJ (eds) Novel phytoplankton blooms: causes and impacts of recurrent brown tides and other unusual blooms. Lecture notes on coastal and estuarine studies. Springer-Verlag, Berlin, p 139-158

Daro $\mathrm{MH}$ (1978) A simplified ${ }^{14} \mathrm{C}$ method for grazing measurements on natural planktonic popoulations. Helgoländer Wiss Meeresunters 31:241-248
Duguay LE, Monteleone DM, Quaglietta C (1989) Abundance and distribution of zooplankton and ichthyoplankton in Great South Bay, New York during the brown tide outbreaks of 1985 and 1986. In: Cosper EM, Bricelj VM, Carpenter EJ (eds) Novel phytoplankton blooms: causes and impacts of recurrent brown tides and other unusual blooms. Lecture notes on coastal and estuarine studies. Springer-Verlag, Berlin, p 599-623

Durbin AG. Durbin EG (1989) Effect of the 'brown tide' on feeding, size and egg laying rate of adult female Acartia tonsa. In: Cosper EM, Bricelj VM, Carpenter EJ (eds) Novel phytoplankton blooms: causes and impacts of recurrent brown tides and other unusual blooms. Lecture notes on coastal and estuarine studies. Springer-Verlag, Berlin, p 625-645

Durbin EG, Durbin AG, Campbell RG (1992) Body size and egg production in the marine copepod Acartia hudsonica during a winter-spring bloom in Narragansett Bay. Limnol Oceanogr 37:342-360

Durbin EG, Durbin AG, Smayda TJ, Verity PG (1983) Food limitation of production by adult Acartia tonsa in Narragansett Bay, Rhode Island. Limnol Oceanogr 28: $1199-1213$

Frost BW (1972) Effects of size and concentration of food particles on the feeding behavior of the marine planktonic copepod Calanus pacificus. Limnol Oceanogr 17:805-815

Frost BW (1980) Grazing. In: Morns I (ed) The physiological ecology of phytoplankton. University of California Press, Berkeley, p 465-491

Gainey LF Jr, Shumway SE (1991) The physiological effect of Aureococcus anophagefferens ('brown tide') on the lateral cilia of bivalve mollusks. Biol Bull 181:298-306

Gallager SM, Stoecker DK, Bricelj VM (1989) Effects of the brown tide alga on growth, feeding physiology and locomotory behavior of scallop larvae (Argopecten irradians). In: Cosper EM, Bricelj VM, Carpenter EJ (eds) Novel phytoplankton blooms: causes and impacts of recurrent brown tides and other unusual blooms. Lecture notes on coastal and estuarine studies. Springer-Verlag, Berlin, $p$ $511-541$

Gifford DJ, Dagg MJ (1991) The microzooplankton-mesozooplankton link: consumption of planktonic protozoa by the calanoid copepods Acartia tonsa Dana and Neocalanus plumchrus Murukawa. Mar Microb Food Webs 5:161-177

Guillard RRL, Ryther JH (1962) Studies of marine planktonic diatoms. I. Cyclotella nana Hustedt, and Detonula confervacea (Cleve) Gran. Can J Microbiol 8:229-239

Harms J (1992) Effects of nutrition (herbivore vs carnivore) on energy charge and nucleotide composition in Hyas araneus larvae. Helgoländer Meeresunters 46:29-44

Jonasdottir SH (1994) Effects of food quality on the reproductive success of Acartia tonsa and Acartia hudsonica: laboratory observations. Mar Biol 121(1):67-81

Jonasdottir SH. Fields D, Pantoja S (1995) Copepod egg production in Long Island Sound, USA, as a function of the chemical composition of seston. Mar Ecol Prog Ser 119: $87-98$

Jonsson PR, Tiselius P (1990) Feeding behavior, prey detection and capture efficiency of the copepod Acartia tonsa feeding on planktonic ciliates. Mar Ecol Prog Ser 60:35-44

Keller MD, Bellows WK, Guillard RRL (1989) Dimethylsulfide production and marine phytoplankton; an additional impact of unusual blooms. In: Cosper EM, Bricelj VM, Carpenter EJ (eds) Novel phytoplankton blooms: causes and impacts of recurrent brown tides and other unusual blooms. Lecture notes on coastal and estuarine studres. Springer-Verlag, Berlin, p 101-115 
Kim WS (1993) Zooplankton community effects on the phytoplankton community in Long Island bays. PhD dissertation, State University of New York at Stony Brook

Kim WS, Chang M (1992) Zooplankton grazing during an euglenoid bloom in Reeves Bay, New York, USA. Ocean Res 14:25-34

Kleppel GS (1992) Environmental regulation of feeding and egg production by Acartia tonsa off southern California Mar Biol 112:57-65

Kleppel GS, Holliday DV, Peiper RE (1991) Trophic interactions between copepods and microplankton: a question about the role of diatoms. Limnol Oceanogr 36:172-178

Lampert W, Fleckner W, Rae H, Taylor BE (1986) Phytoplankton control by grazing zooplankton: a study on the spring clear-water phase. Limnol Oceanogr 31:478-490

Lampert W. Taylor BE (1985) Zooplankton grazing in a eutrophic lake: implications of diel vertical migration Ecology 66:68-82

Landry MR (1981) Switching between herbivory and carnivory by the planktonic marine copepod Calanus pacifi cus. Mar Biol 65:77-82

Landry MR, Lehner-Fournier JM (1988) Grazing rates and behaviors of Neocalanus plumchrus: implications for phytoplankton control in the subartic Pacific. Hydrobiologia $167 / 168: 9-19$

Lively JS, Kaufman Z, Carpenter EJ (1983) Phytoplankton ecology of a barrier island estuary: Great South Bay, New York. Estuar Coast Shelf Sci 16:51-68

Lonsdale DJ, Cosper EM (1994) Phytoplankton productivity and zooplankton feeding and productivity in the lower Hudson River estuary. Final Report to the Hudson River Foundation. Hudson River Foundation, New York

Lonsdale DJ, Coull BC (1977) Composition and seasonality of zooplankton of North Inlet, South Carolina. Chesapeake Sci 18:272-283

Lonsdale DJ, Heinle DR, Siegfried C (1979) Carnivorous feeding behavior of the adult calanoid copepod Acartia tonsa Dana. J Exp Mar Biol Ecol 36:235-248

Lonsdale DJ, Levinton JS (1985) Latitudinal differentiation in copepod growth: an adaptation to temperature. Ecology 66:1397-1407

Lonsdale DJ, Weissman P, Dobbs FC (1993) A reproductiveresting stage in an harpacticoid copepod, and the significance of genetically based differences among populations. Bull Mar Sci 53:180-193

Malej A, Harris RP (1993) Inhibition of copepod grazing by diatom exudates: a factor in the development of mucus aggregates. Mar Ecol Prog Ser 96:33-42

Marshall SM (1973) Respiration and feeding in copepods. Adv Mar Biol 11:57-120

Nuzzi R, Waters RM (1989) The spatial and temporal distribution of 'brown tide' in eastern Long Island Sound. In: Cosper EM, Bricelj VM, Carpenter EJ (eds) Novel phytoplankton blooms: causes and impacts of recurrent brown tides and other unusual blooms. Lecture notes on coastal and estuarine studies. Springer-Verlag, Berlin, p 117-138

Pierce RW, Turner JT (1992) Ecology of planktonic ciliates in marine food webs. Rev Aquat Sci 6:139-181

Putt M, Stoecker DK (1989) An experimentally determined carbon:volume ratio for marine 'oligotrichous' ciliates from estuarine and coastal waters. Limnol Oceanogr 34: $1097-1103$

Robertson JR (1983) Predation by estuarine zooplankton on tintinnid ciliates. Estuar Coast Shelf Sci 16:27-35

Roman MR, Ashton KA. Gauzens AL (1988) Day/night differences in the gazing impact of marine copepods. Hydrobiologia 167/168:21-30
Roman MR, Rublee PA (1981) A method to determine in situ zooplankton grazing rates on natural particle assemblages. Mar Biol 65:303-309

Rothschild BJ, Osborn TR (1988) Small-scale turbulence and plankton contact rates. J Plankton Res 10:465-474

Sherr Bt, Sherr EB, Hopkinson CS (1988) Trophic interactions within pelagic microbial communities: indications of feedback regulation of carbon flow. Hydrobiologia 159:19-26

Sherr EB, Sherr BF, McDaniel J (1991) Clearance rates of $<6 \mu \mathrm{m}$ fluorescently labeled algae (FL.A) by estuarine protozoa: potential grazing impact of flagellates and clliates. Mar Ecol Prog Ser 69:81-92

Sieburth J McN, Johnson PW, Hargraves PE (1989) Picoplankton ultrastructure: a decade of preparation of the brown tide alga, Aureococcus anophagefferens. In: Cosper EM, Bricelj VM, Carpenter EJ (eds) Novel phytoplankton blooms: causes and impacts of recurrent brown tides and other unusual blooms. Lecture notes on coastal and estuarine studies. Springer-Verlag. Berlin, p 1-22

Sokal R.R, Rohlf FJ (1981) Biometry. WH Freeman, San Francisco

Stoecker DK, Capuzzo JM (1990) Predation on protozoa: its importance to zooplankton. J Plankton Res 12:891-908

Stoecker DK, Davis LH, Provan A (1983) Growth of Favella sp. (Ciliata: Tintinnina) and other microzooplankters in cages incubated in situ and comparison to growth in vitro. Mar Biol 75:293-302

Stoecker DK, Egloff DA (1987) Predation by Acartia tonsa Dana on planktonic ciliates and rotifers. J Exp Mar Biol Ecol 110:53-68

Strathmann RR (196,) Estimating the organic carbon content of phytoplankton from cell volume or plasma volume. Limnol Oceanogr 12:411-418

Strickland JD, Parsons TR (1972) A practical handbook of seawater analysis. Bull Fish Res Bd Can 167

Tackx MLM, Daro MH (1993) Influence of size dependent " C uptake rates by phytoplankton cells in zooplankton grazing measurements. Cah Biol Mar 34:253-260

Tandichodok. P (1990) Relative importance of phytoplankton and organic detritus as food resources for the suspensionfeeding bivalve Mytilus edulis L. in Long Island Sound. PhD dissertation, State University of New York at Stony Brook

Tester PA, Turner JT (1991) Why is Acartia tonsa restricted to estuarine habitats? In: Proceedings of the Fourth International Conference on Copepoda, Karuizawa, Japan. Bull Plank Soc Jap Spec Vol, p 603-611

Turner JT (1982) The annual cycle of zooplankton in a Long Island estuary. Estuaries 5:261-274

Turner JT, Anderson DM (1983) Zooplankton grazing during dinoflagellate blooms in a Cape Cod embayment, with observations of predation upon tintinnids by copepods. PSZN I: Mar Ecol 4:359-374

Turner JT, Granéli E (1992) Zooplankton feeding ecology: grazing during enclosure studies of phytoplankton blooms from the west coast of Sweden. J Exp Mar Biol Ecol 157:19-31

Verity PG (1985) Grazing, Iespiration, excretion, and growth rates of tintinnids. Limnol Oceanogr 30:1268-1282

Verity PG, Langdon C (1984) Relationships between lorica volume, carbon, nitrogen, and A.TP content of tintinnids in Narragansett Bay. J Plankton Res 6:859-868

White JR, Roman MR (1992a) Egg production by the calanoid copepod Acartia tonsa in the mesohaline Chesapeake Bay: the importance of food resources and temperature. Mar Ecol Prog Ser 86:239-249

White JR, Roman MR (1992b) Seasonal study of grazing by metazoan zooplankton in the mesohaline Chesapeake Bay. Mar Ecol Prog Ser 86:251-261
This article was presented by D. A. Caron (Senior Editorial Advisor), Woods Hole, Massachusetts, USA 